\title{
"Nothing Is Like It Was Before": The Dynamics between Land-Use and Land-Cover, and Livelihood Strategies in the Northern Vietnam Borderlands
}

\section{Sarah Turner ${ }^{1, *}$ and Thi-Thanh-Hiên Pham ${ }^{2}$}

1 Department of Geography, McGill University, 805 rue Sherbrooke Ouest, Montréal, QC H3A 0B9, Canada

2 Département D'études Urbaines et Touristiques, Université du Québec à Montréal, 315 rue Sainte-Catherine Est, Montréal, QC H2X 3X2, Canada;

E-Mail: pham.thi_thanh_hien@uqam.ca

* Author to whom correspondence should be addressed; E-Mail: sarah.turner@mcgill.ca; Tel.: +1-514-398-4955.

Academic Editors: Claudia A. Radel and Jacqueline M. Vadjunec

Received: 28 July 2015 / Accepted: 9 November 2015 / Published: 18 November 2015

\begin{abstract}
Land uses are changing rapidly in Vietnam's upland northern borderlands. Regional development platforms such as the Greater Mekong Subregion, state-propelled market integration and reforestation programs, and lowland entrepreneurs and migrants are all impacting this frontier landscape. Drawing on a mixed methods approach using remote sensing data from 2000 to 2009 and ethnographic fieldwork, we examine how land-use and land-cover change (LULCC) has occurred across three borderland provinces-Lai Châu, Lào Cai and Hà Giang - with high proportions of ethnic minority semi-subsistence farmers. After a broad examination of regional land-use changes, we select three case studies to further analyze the underlying relationships between specific LULCC and local livelihood diversification strategies. These include specific patterns of urban growth due to a range of political decisions in Lai Châu and Lào Cai Provinces; reforestation due to nontimber forest (NTFP) product cultivation in the west of Lào Cai Province; and a stable landscape that restricts government attempts at refashioning upland livelihoods in the east of Hà Giang. Our findings point to the difficulties of completing LULCC maps for this highly heterogeneous region and the complexity of LULCC and livelihood interactions and relationships examined on the ground.
\end{abstract}


Keywords: livelihood diversification; ethnic minorities; northern Vietnam; land-use and land-cover change; reforestation; cardamom; urbanization; mixed methods

\section{Introduction}

Two hundred million people, more than half of whom are ethnic minorities, reside in the Southeast Asian Massif, a broad expanse of uplands extending southeast from the Himalayan Plateau and shared today among 10 countries. Dwelling on the physical, economic, and often cultural fringes of their respective states and predominantly undertaking semi-subsistence rural agriculture, residents of these frontiers face numerous land-use and livelihood challenges. While studies of the causal mechanisms of land-use and land-cover change (LULCC) in the Southeast Asian Massif are growing [1-5], there remains an urgent need to refine our understandings of how and why potential factors - be they socio-economic, political, or ecological - underpin land-use changes in these uplands. Not only do we need to better comprehend how specific land policies and market-led changes, for instance, drive LULCC, but also how depleted soil nutrients, population growth, or household agricultural knowledge can trigger land-use change [6]. Furthermore, since rural household livelihoods often have direct relationships with land use, the interactions between land-use change and livelihoods merit greater attention [7-10].

The livelihoods of those residing in the Southeast Asian Massif are undergoing important transformations due to market integration, agrarian transformations, globalization, and the closing of land frontiers. Indeed, political scientist James C. Scott in his 2009 book, The Art of Not Being Governed, noted that since 1945, these uplands have become increasingly claimed and incorporated by modern states through processes labeled as "development, economic progress, literacy, and social integration" ([11]; p. 4). For most local residents, this has resulted in the replacement of communal property with private land-use rights, the establishment of cash cropping, and a drive to convert shifting cultivators into permanent farmers. One such regional development approach is the Greater Mekong Sub-Region (GMS), which aims to connect the uplands of Vietnam, Cambodia, Laos, Myanmar, Thailand, and Yunnan Province, China. Via the GMS project alone, the Asian Development Bank (ADB) and regional states have poured more than US\$14 billion into infrastructure, including highways and railways, telecommunications, and energy and urban development [12,13]. With this region also increasingly targeted by state officials and private entrepreneurs for natural resource extraction and agrarian possibilities, livelihood approaches and land-use patterns are being impacted profoundly $[14,15]$.

Within the Southeast Asian Massif, Vietnam's northern borderlands - with their complex political context on the Chinese border, ethnic diversity, and dynamic frontier location - provide an important case study with which to examine the mechanisms of LULCC through a livelihood lens. These borderlands are undergoing critical socio-economic transformations created by both trans-national and local forces. Two of the most notable implications for LULCC are increasing urbanization and changing forest dynamics. Urbanization, supported by the government's pro-urban policies since economic reforms were initiated in the mid-1980s (Đổi Mói i) [16], is increasing market interactions and opening up possibilities of new livelihood diversification trajectories for local populations. Forest changes, including 
deforestation, afforestation (often for timber production), and reforestation (natural succession, as well as production policies) are in turn impacted by interwoven and oftentimes conflicting land-use and forest policies [14], creating different livelihood opportunities as well as restrictions.

In this paper we examine how livelihoods and LULCC are intertwined within three of Vietnam's northern borderland provinces, namely Lai Châu, Lào Cai, and Hà Giang. Each province is home to a high proportion of ethnic minority semi-subsistence farmers. We focus specifically on the 14 border districts of these three study provinces (Figure 1) and temporally, on changes that have occurred from 2000 to $2009 .^{1}$ After examining meso-level results across our study region, we select three case studies and examine the underlying relationships between specific LULCC and local livelihood diversification strategies by combining quantitative mapping with qualitative fieldwork in a mixed methods approach. Such an approach is increasingly recognized and promoted by scholars from different disciplinary backgrounds to provide insight into the causes of land-use change [17]. We find that combining ethnographic fieldwork with land-cover change mapping reveals hidden causes of LULCC in these three provinces. For instance, specific patterns of urban growth have been caused by pro-urban policies, cross-border trade, political boundary redrawing, and resettlement in Lai Châu and Lào Cai Provinces. In the west of Lào Cai Province, reforestation has occurred due to the increased cultivation of cardamom, a non-timber forest product (NTFP), while in the east of Hà Giang a particular landscape has restricted government attempts at refashioning upland livelihoods from those already built around local maize cultivation.
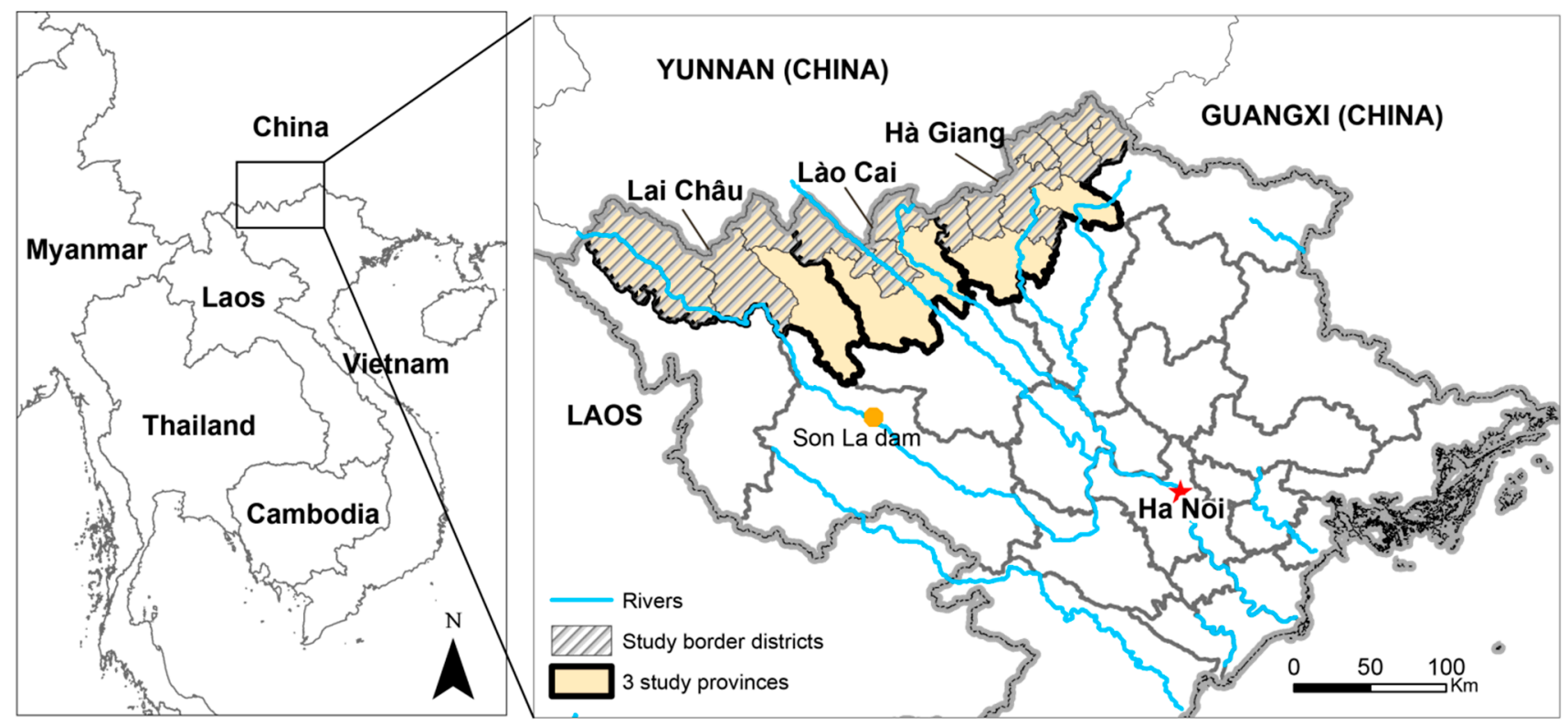

Figure 1. Location of the study border districts and provinces in northern Vietnam.

\section{Conceptual Framework: Land Change Science, Frontiers and Livelihood Diversification}

Conceptually, we draw from land change science (LCS), frontier studies, and livelihood diversification literature. LCS is an emerging interdisciplinary area of study that "focuses on material

\footnotetext{
${ }^{1}$ These years correspond with the last two national censuses completed for Vietnam (1999 and 2009), and the most unobstructed satellite images available. They also cover a dynamic time in the contemporary political and economic history of the uplands.
} 
related to the nature of land use and land cover, their change over space and time, and processes that produce those patterns and changes"([9]; p. 3). We direct attention to three of the core objectives of LCS, namely the observation of land changes, understanding the causes of these changes, and assessing their impacts [9,18-20]. Of specific note here are causes of LULCC, which can be separated into predisposing environmental factors, underlying forces, and proximate causes [21]. Predisposing environmental factors include elevation, slope, soil conditions, and natural disasters. Underlying causes can include population, economic change, policy, ethno-cultural aspects, and technology [21]. Proximate causes are activities that directly alter land use. For example, one common proximate cause of deforestation is agricultural expansion, which could be the result of an underlying cause such as population growth or in-migration [22].

Frontier regions are both physical entities and social constructs [23,24]. Frontier studies are important to help analyze the degree to which the Sino-Vietnamese borderlands are experiencing natural resources extraction, agricultural intensification, in-migration, increasing cross-border exchanges, and state control $[25,26]$ —all of which are altering land use and land cover in the region. Frontier regions offer numerous economic attractions such as access to natural resources, newfound business opportunities, and cross-border employment and trade prospects [13,27-32]. Agricultural expansion and natural resource exploitation are two particularly common vectors of frontier exploitation by both state and private entrepreneurs [33-36], often resulting in "spontaneous land opening, environmental degradation and the taming of ethnic minorities" ([37]; p. 14). Moreover, culturally speaking, frontier regions are often depicted as "backward" and in need of improvement, in contrast with the relative social and cultural "modernity" and dominance of the core [24,38], in this case the majority Vietnamese (Kinh or Việt) lowlands. Used to ease demographic pressure on core areas, state and private investment in frontier regions across the Southeast Asian Massif has also been argued to establish territorial domination by the state, further integrating ethnic minorities into the Nation [11,26,39].

For some, livelihoods in this region are changing substantially as one livelihood portfolio is replaced by another, such as when agricultural semi-subsistence is replaced by waged labor in a rural town. Yet more frequently, households undergo livelihood diversification, "the process by which rural families construct a diverse portfolio of activities and social support capabilities in their struggle for survival and in order to improve their standards of living" ([40]; p. 4). Livelihood diversification needs to be examined through a dynamic analysis incorporating the context-specific sociocultural (e.g., ethnic, gender, class), environmental, historical, and spatial dynamics of how people create and sustain viable and meaningful livings [41,42]. In turn, these responses are situated within broader spheres of institutional knowledge and power, with social actors supported or constrained by discrepancies in access to resources and information [43-45]. In rural locales in the Global South, livelihood diversification is often closely linked with changing land uses and, in turn, changes in land cover [10,46,47].

Together, these three bodies of literature inform each other and allow us to better interpret the LULCC that we find in Vietnam's northern uplands. This conceptual framing offers an integrated approach to examining the processes and results of changing land cover and land use as well as how they are interwoven with livelihood diversification decision making, power relations, access regimes, institutions, and state-society relations in this political and cultural frontier zone. Yet, combining these three conceptual approaches is challenging, as they are rooted in different paradigms, and, hence, use 
different research methodologies. Land change scientists usually use statistical models to identify environmental and socio-economic determinants of LULCC, but social scientists often criticize such methodological approaches as oversimplifying and generalizing social groups, and hence omitting intra-group livelihood diversity [17]. Combining such conceptual approaches thus needs to be done with caution, as explored below.

\section{Context: Vietnam's Northern Uplands}

The Socialist Republic of Vietnam recognizes 54 ethnic groups: the majority lowland Vietnamese and 53 "national minorities" (các dân tộc thiểu số). Though the latter comprise 14.8 percent of Vietnam's population [48], in the three upland provinces of Lai Châu, Lào Cai, and Hà Giang (Figure 1), ethnic minorities are in fact in the majority. They comprise 87 percent of the total population of 724,000 in Hà Giang Province, 85 percent in Lai Châu (total pop. 370,000), and 66 percent in Lào Cai (total pop. 614,000) [48]. Many of these ethnic minorities, such as the Hmong and Yao (Dao), belong to geographically-dispersed, politically-fragmented, lineage-based minority populations [49-51]. These populations frequently undertake diversified livelihoods through a composite agricultural system. A combination of maize and rice fields are commonly mixed with home gardens, small (officially banned) swidden plots, the gathering of firewood, honey, and herbs from forests, as well as small-scale commercial exchanges of cardamom, livestock, textiles, or homemade alcohol [15,52].

Land access and quality play central roles for these livelihoods, while it must be remembered that all land in Vietnam is officially owned by the state. Land-use rights have been assigned to households since the 1993 Land Law, following the dismantlement of socialist collectives in 1988, initiated by Resolution 10 [53,54]. Forests are also important for many upland livelihoods, providing fuel wood and non-timber forest products. The northern Democratic Republic of Vietnam (DRV) designated all hills and mountains with slopes over $25^{\circ}$ as forestland in 1954 and founded a series of State Forest Enterprises (SFEs) [55,56]. These SFEs have had rather ambiguous functions, logging forests in some areas, while driving reforestation endeavors in others. Nonetheless, forest cover for the whole country dropped to 30 percent by 1985 due to the actions of these SFEs and individual farmers [57]. After the initiation of the Đổi Mới economic reforms of the mid-1980s that shifted Vietnam to a more open economy from a stricter socialist one [58], reforestation and forest protection became a priority in state policy (e.g., the 1991 Act on Forest Protection and Development and the 2004 Forest Protection and Development Law). A new management system was introduced with three classifications of forests: production forests (for timber extraction); protection forests (especially around watersheds); and special-use forests (focusing on strict preservation for biodiversity and cultural values) [59]. These classifications were integrated into the 1993 Land Law, which initiated a distribution of land tenure certificates providing production forest or protection forest allocations to upland households [60]. Through the late 1990s, a forest transition is thought to have occurred due not only to this classification of forests, but also due to a ban on opium and logging implemented in 1992/93, further reforestation programs including the "Greening the Barren Hills Program" (also named Program 327) from 1992, a similar program labeled Program 556, and the "Five Million Hectare Reforestation Program" from 1998. Nonetheless, the outcomes of these reforestation programs have been rather ambiguous, as case studies suggest that forest density and quality are diminishing [56,61-63]. 
The agricultural systems of upland ethnic minority groups have likewise undergone rapid transformations, including an expansion of wet rice farming due to migration of lowland Vietnamese from the Red River Delta since the 1960s and the Đổi Mói economic reforms. A move from swidden farming to fixed crops has been encouraged by the granting of long-term land-use rights to households as well as the introduction of high-yield hybrid rice and maize seeds since 1999 [26]. A transition from subsistence crops to cash crops in some regions has also been driven by the expansion of the market economy [2,52]. In addition, since 2000, new exogenous factors such as increasing weather extremes, and the 2008 food price crisis have further impacted livelihoods in these communities.

LULCC studies in upland Vietnam have started to analyze such transformations since the country's independence in 1954 [1,2,61,62,64-66]. However, all these studies have been conducted elsewhere in the country, either in the Central Highlands or in northern provinces at lower altitudes and more closely connected to the capital, Hanoi, than the borderlands. In addition, apart from our own prior research [14,67] including a systematic literature review, no study has addressed the relationships between LULCC and livelihoods along the northern borderlands with their ethnically diverse, quantitatively "poor" populations compared to the rest of the country [57] (but see [68] with one case study in a borderland district and [5] with a study neighboring, but not in, a borderland district). Consequently, LULCC dynamics in the northern border uplands - a political, resource, and cultural frontier-remain poorly understood.

\section{Methods}

Taking a mixed methods approach, this study draws on both quantitative and qualitative methods, namely land-cover change mapping and ethnographic interviews. More specifically, we take an "interactive design" to mixed methods, in that our approach emphasizes quantitative and qualitative methods equally. We do not, however, aim for data transformation (e.g., we do not take our qualitative data and transform them into quantifiable data for statistical analysis). Instead, we aim for "data importation", namely that data from one approach was reflected upon mid-stream in our analysis, and fed into the analysis of the other data set, and vice versa in an iterative manner [69]. We began by mapping land-cover change via remote sensing. We then chose cases representing the most important dynamics between LULCC and livelihoods, and drew on previous interviews completed since 1999 regarding livelihoods as well as additional interviews and observations focusing on the case sites during the summers of 2012, 2013, and 2014 to guide our interpretations. An important element in this interactive process was our long-term knowledge of the region, which allowed us to be confident about our choice of cases.

\subsection{LULC and LULCC Mapping}

Given the lack of accurate data regarding land use in rural Vietnam, especially historical data [70], we had to compromise somewhat methodologically, opting for an analysis of a mixed system of land-use and land-cover types. LULC maps were derived from Landsat thematic mapper (TM5) and enhanced thematic mapper (ETM+) images obtained from the United States Geological Survey (USGS). All images were taken during the winter season (Table 1) when sparse vegetable crops were growing, with no maize or wet rice. To identify land-cover types from our Landsat images, we drew on the Level I 
land-cover types proposed by Anderson in 1976 [71] and previous LULCC studies of Vietnam using Landsat images [52,61].

Table 1. Dates of images.

\begin{tabular}{cc}
\hline Province & Dates \\
\hline \multirow{2}{*}{ Lai Châu } & 2009 November 03 \\
& 2000 November 02 \\
\hline \multirow{2}{*}{ Lào Cai } & 2009 November 12 \\
& 1999 December 27 \\
\hline \multirow{2}{*}{ Hà Giang } & 2009 November 05 \\
& 2000 November 04 \\
\hline
\end{tabular}

Initially, we identified five key land-cover types across the study region from satellite images (shrubs, bare soil, open canopy trees, closed canopy trees, and water). To provide further detail, we then added one land-use type, namely built-up areas, working from the five original land-cover types. It should be noted that there is rarely any grassland in this mountainous area; when small patches of grass are mixed up with shrubs, we identify them only as "shrubs". Cropped land is composed of subsistence crops (lowland and upland rice, corn, cassava) and cash crops (banana, pineapples, tobacco, among others). According to our interviews and local crop calendars, areas with subsistence crops are often covered by bare soil in the winter, when our images were acquired. This is also observed in other upland areas of Vietnam [4,52,61]. Pineapples are small and fairly dispersed plants, hence pineapple areas are spectrally similar to bare soil in the images. Areas having bananas remain vegetated and identified as shrubs in the Landsat images. However, bananas were not very common in the region in 2009 (interviews and observations), and were usually found next to houses or mixed with shrubs. Built-up areas are also identified as bare soil in the images, although dense urban areas have stronger spectral reflectance. To separate built-up from cropped land, we used information regarding road systems (see below). Open canopy trees in this region tend to be bamboo, plantations for timber production, or natural succession since the 1990s (interviews). Closed canopy trees are old and nearly intact forests that are often protected by the local government, such as special-use forests (often labeled national parks). This class has sometimes been called "mature and evergreen forest" in Southeast Asian forest studies [72]. Separating forests into two categories — open and closed canopy-is usual in Southeast Asian upland studies [4], although some authors tend to group them into one category $[61,73]$. Interpretation of classification results was done with these details in mind. Illustrations of these LULC types are presented in Figure 2, while we detail our classification method below.

The images were pre-processed to remove distortions caused by sensor errors, atmospheric interference, and surface irregularities. Cloud and cloud shadow masking was conducted on the 2000 image of Lai Châu and the 2009 image of Lào Cai (more specific technical details are provided in [14]). We used an object-based approach [74] to identify the five land-cover types listed above plus clouds and shadow. Although associated most often with very high-resolution images, this approach has proven accurate to produce rural land-cover types from middle-resolution images such as Landsat [75,76]. Cultivation systems in upland Southeast Asia are complex, mixing young forest, shrubs, and different types of crops [52,72]. In this context, an object-based approach is very helpful in creating segments (objects) 
and incorporating textural information of segments into classification. This approach has also allowed us to work at two spatial levels: segmentation of large-size patches (to separate large-scale forest and crops) and of small-size patches with relatively homogenous texture and signals (to identify smaller plots).

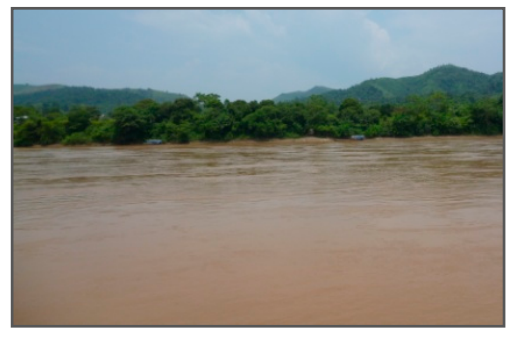

Water (Red River, near Lào Cai City)

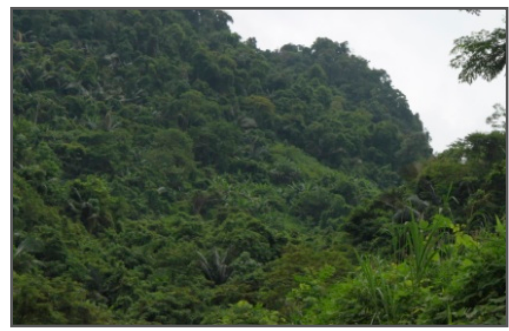

Closed canopy trees

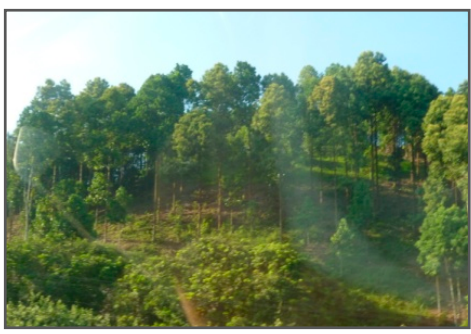

Open canopy trees

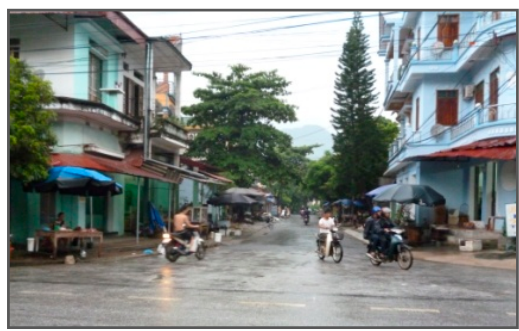

Built-up areas

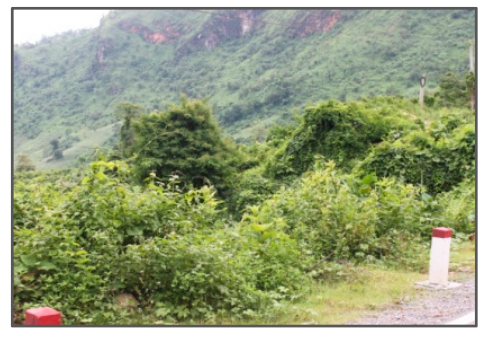

Shrubs

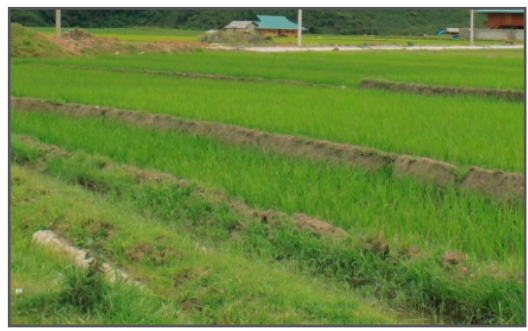

Rice (bare soil in winter)

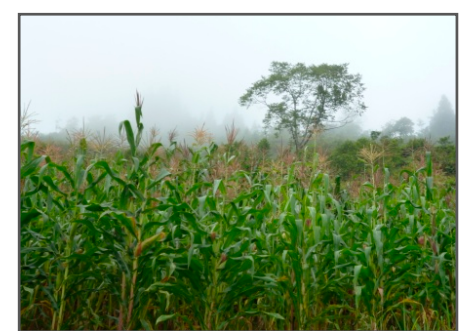

Corn (bare soil in winter)

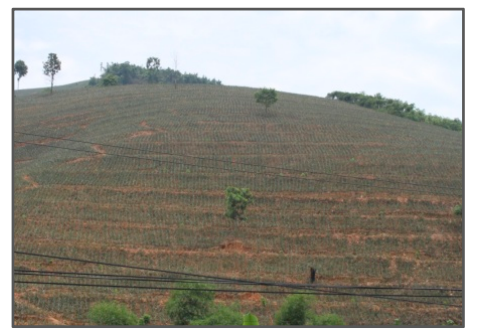

Pineapples

Figure 2. Illustration of the six LULC classes. (Photo credit: Lê Mạnh An, Thi-Thanh-Hiên Pham).

Segmentation parameters in eCognition (bands, scales, color/shape ratio, and compactness/smoothness ratio) were tested at different values. Segmentations and rule-based classifications were undertaken at different scales using the same band composition (bands 1-5, 7), color/shape ratio $(0.2 / 0.8)$, and compactness/smoothness ratio (0.3/0.7). Segmentation values of 5, 10, 20, 50, 100, and 200 were tested, aiming at creating segments of different sizes. Segments were visually examined to determine the visibility of the main land-cover classes. We chose two values that produced the most homogenous segments in terms of spectral values and texture. The first segmentation was conducted at a scale of 50 to obtain large size objects. Rules were then used to classify those objects into clouds and shadow, water, and bare soil classes. The second segmentation was conducted at a scale of 10 , then a second set of rules 
was used to classify segments into three vegetation classes of shrubs, open canopy trees, and closed canopy trees.

Bare soil was then separated into bare soil and built-up. Built-up pixels were assigned by evaluating road density. The road network was separated into solid (gravel or concrete) and non-solid (compacted soil susceptible to flooding during the rainy season) roads. A density map was developed by assigning solid roads an importance value of 3 and non-solid roads a value of 1 . Pixels having high road density (3m/ $\mathrm{km}^{2}$ in 1999 and $4 \mathrm{~m} / \mathrm{km}^{2}$ in 2009) were visually compared to aerial images on Google Earth and those that coincided with more urban areas (built-up and having a street network) were renamed as built-up. The remaining bare soil pixels remained bare soil.

We did not use a set of training points per se to define rules of classification. Rather, we chose roughly 200 objects (segments) that corresponded to land-cover types that we knew on the ground from observations. Then we created rules composed of textural and spectral indicators for each class from the chosen objects. Refining and adjusting rules were based on interactive "trial and error". The classification process included initial field observations in summer 2013, and field verification in summer 2014 by the second author.

\subsection{Assessing the LULC Mapping}

A ground truth assessment was conducted for the 2009 classification by using ground control points (GCPs). There are no historical air photos for the region covering 1999/2000. There are a few photos on Google Earth from 2009/2010 but they are dispersed and cover only 15 percent of the study area. We hence opted for GCPs. We collected 365 GCPs: 142 points in Lào Cai Province (September 2012), 101 points in Lai Châu, and 122 points in Hà Giang (September 2013). Given the difficult access to many locations in the region, points were sampled along roads, focusing on typical land-cover types in the region. There were fewer points in Lai Châu given the lack of roads and access difficulties caused by landslides.

Each point was registered in GPS (precision of 5m) and photographed in the four cardinal directions to capture potential mixtures of land cover. Descriptions of land use and land cover were included at each point and for the four directions. Land-cover types were assigned to each point based on photos and descriptions. Unfortunately, we do not have ground points for the 1999 images, but since we used the same image processing procedure for the 1999 and 2009 images, we believe that the accuracies of the 1999 images are similar to those of the 2009 images.

In order to evaluate the accuracy of the 2009 classification, we created a confusion matrix (Table 2) using the 365 GCPs. The overall accuracy is 71 percent, mostly due to confusions between open canopy and closed canopy classes. Accuracies varied from 46 percent (open canopy) to 96.88 percent (closed canopy). In this mountainous area undergoing complex forest transitions, open canopy trees are usually mixed with shrubs, making it difficult to separate them from Landsat images. The confusion between open canopy and closed canopy is most likely due to the fact that open forests in the three provinces are highly heterogeneous. What is defined on the ground as open canopy in areas with plantations (since the mid-1990s) could be similar spectrally to closed canopy in other areas. When grouping these two categories into "forest" (as done in several Southeast Asian LULCC 
studies [61,73]), we obtained a "user accuracy" of 79.30 percent and a "producer accuracy" of 72.22 percent, raising overall accuracy to 73.70 percent.

Other important confusions related to bare soil, our proxy for rice or corn fields. In these mountainous areas, dispersed houses and remote roads are often located close to rice or corn fields, creating a spectral mixture in the image. In Đồng Văn District, Hà Giang Province, this gets complicated further by limestone outcrops within fields and near houses (Figure 3a). Lastly, the confusion between shrubs and bare soil is explained by the fact that upland dry rice and maize are commonly planted in areas close to shrubs (Figure $3 b$ ).

Table 2. Confusion matrix and producer's and user's accuracy for accuracy assessment of the 2009 classification (based on ground control points).

\begin{tabular}{|c|c|c|c|c|c|c|c|c|c|}
\hline & & \multicolumn{6}{|c|}{ Ground Reference } & \multirow{2}{*}{ Total } & \multirow{2}{*}{$\begin{array}{l}\text { Producer } \\
\text { Acc. }(\%)\end{array}$} \\
\hline & & Water & Closed Canopy & Open Canopy & Shrubs & Bare Soil & Built-Up & & \\
\hline \multirow{6}{*}{ Classification } & Water & 16 & 0 & 0 & 0 & 1 & 2 & 19 & 84.21 \\
\hline & Closed canopy & 3 & 31 & 10 & 7 & 3 & 0 & 54 & 57.41 \\
\hline & Open canopy & 0 & 1 & 23 & 8 & 2 & 2 & 36 & 63.89 \\
\hline & Shrubs & 0 & 0 & 13 & 42 & 7 & 2 & 64 & 65.63 \\
\hline & Bare soil & 3 & 0 & 3 & 10 & 109 & 11 & 136 & 80.15 \\
\hline & Built-up & 0 & 0 & 1 & 3 & 15 & 37 & 56 & 66.07 \\
\hline \multicolumn{2}{|c|}{ Total } & 22 & 32 & 50 & 70 & 137 & 54 & 365 & \\
\hline \multicolumn{2}{|c|}{ User Acc. (\%) } & 72.73 & 96.88 & 46.00 & 60.00 & 79.56 & 68.52 & & \\
\hline
\end{tabular}

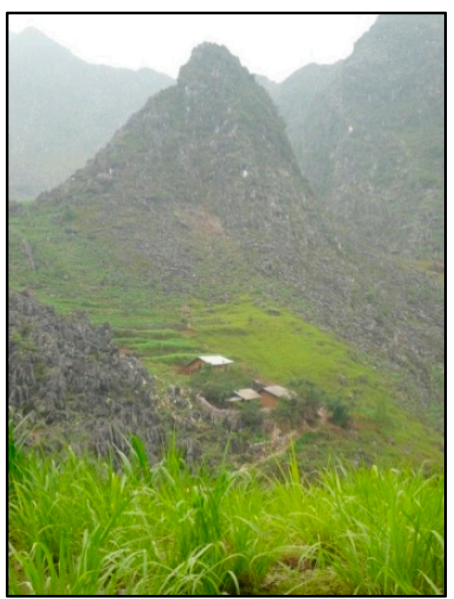

(a)

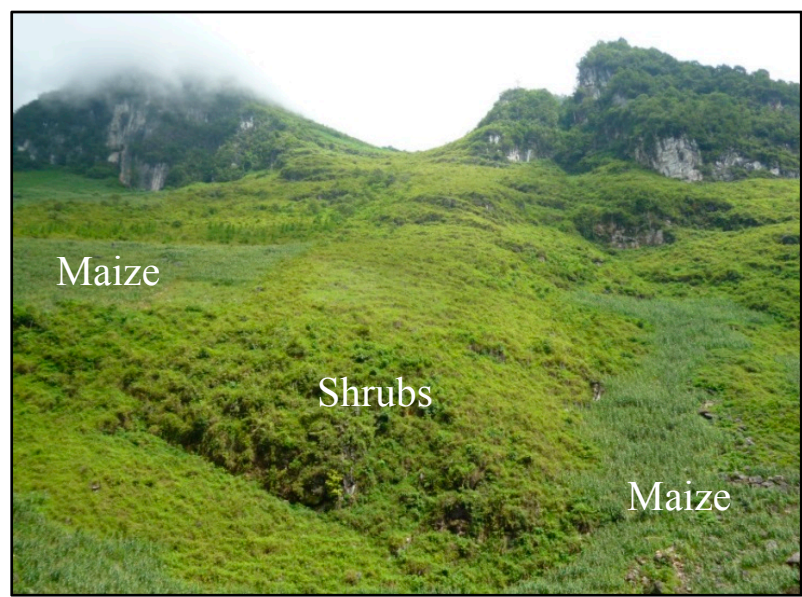

(b)

Figure 3. (a) Typical karst landscape and (b) mixture of maize and shrubs in Đồng Văn District, Hà Giang Province. (Photo credit: Sarah Turner and Lê Mạnh An).

\subsection{Computing LULCC}

To measure LULCC, we computed the percent change and the annual rate of change for each class, where $A 1$ is the cover of arable land at an initial time $\left(t_{1}\right)$ and $A 2$ is the cover of arable land at a later time ( $\left.t_{2}\right)$, and where $t=t_{2}-t_{1}$ (Equations (1) and (2)) [77].

$$
R=\frac{\mathrm{A} 2-\mathrm{A} 1}{\mathrm{~A} 1}
$$




$$
\text { Rate }=\ln (A 2 / A 1) / t
$$

We also computed the absolute values of changes for each LULCC type per district. In other words, we computed the magnitude of change ( $R$ in Equation (1)) without taking into consideration the direction of change (decreasing or increasing over time) because we wanted to capture the total amount of relative change. Finally, in order to adjust the changes by size of district, we computed the ratio of absolute value of change over the district area (without including areas covered by clouds and shadow). This allowed us to identify the most dynamic and the most stable districts in terms of LULCC. The higher the ratio, the more dynamic the district with regards to LULCC.

\subsection{Qualitative Fieldwork}

The qualitative fieldwork that supports this study was completed by the first author during repeated research visits to Lào Cai Province since 1999, Lai Châu Province since 2004, and Hà Giang Province since 2009, and by the second author in Lào Cai Province since 2012. This includes over 100 in-depth unstructured (conversational) interviews with ethnic minority farmers (Tày, Hmong, Yao, Nùng) in Lào Cai Province, and 50 each in Lai Châu and Hà Giang Provinces. Approximately 75 percent of farmer interviewees were women, as they were more likely to be in the house during the day, yet had a wide knowledge of land uses and changes. Farmer ages ranged from 25 to 80 years old. Interviews ranged in duration from 20 minutes to over an hour, focusing on local livelihood diversification, agricultural practices, land-use changes, and state-society relations. Twenty-eight semi-structured interviews were also completed with provincial officials (mostly Kinh) working in government departments linked to agriculture, planning, labor, and natural resources. The core themes of these interviews were livelihoods, market integration, land-cover change, and the impacts of state policies on each of these. Interviews were completed with the aid of local ethnic minority interpreters for farmers of the same ethnicity, or with Kinh interpreters or alone for Kinh farmers, urban dwellers, and state officials. All interviews were transcribed and coded using a mix of constant comparative, axial, and thematic qualitative coding approaches. Concurrently, observations of LULCC have been completed and noted annually.

\section{Results}

Our land-cover mapping shows that the most important changes in terms of area (Table 3) include an increase in closed canopy forest $\left(2437 \mathrm{~km}^{2}\right)$, followed by a decrease in open canopy forest (roughly $\left.1694 \mathrm{~km}^{2}\right)$, a decrease in bare soil $\left(537 \mathrm{~km}^{2}\right)$, and a decrease in shrubs $\left(324 \mathrm{~km}^{2}\right)$. Examining the 2000 and 2009 maps (Figure 4), spatial patterns for these changes are visible. The increase in closed canopy forest is most notable in all the border districts of Lào Cai Province (except Si Ma Cai and Lào Cai City), in Mường Tè District (Lai Châu Province), and in the southwestern parts of Hà Giang Province (also see Table 4). In turn, a decrease in open canopy forest has occurred in almost all these same locales where closed canopy forest increased. 
Table 3. Land-cover change in the region, 2000-2009.

\begin{tabular}{cccccc}
\hline Land Cover & $\begin{array}{c}\text { Area in } \\
\mathbf{2 0 0 0}\left(\mathbf{k m}^{\mathbf{2}}\right)\end{array}$ & $\begin{array}{c}\text { Area in } \\
\mathbf{2 0 0 9}\left(\mathbf{k m}^{\mathbf{2}}\right)\end{array}$ & $\begin{array}{c}\mathbf{2 0 0 9 - 2 0 0 0} \\
\left.\text { Area Change } \mathbf{( k m}^{\mathbf{2}}\right)\end{array}$ & $\begin{array}{c}\mathbf{2 0 0 9 - 2 0 0 0} \\
\text { Percent Change (\%) }\end{array}$ & $\begin{array}{c}\text { Annual Rate of } \\
\text { Change (\%/year) }\end{array}$ \\
\hline Closed canopy & 1723.89 & 4161.03 & 2437.14 & 141.37 & 8.81 \\
Open canopy & 3281.12 & 1587.14 & -1693.98 & -51.63 & -7.26 \\
Shrubs & 3357.08 & 3033.28 & -323.80 & -9.65 & -1.01 \\
Bare soil & 3668.91 & 3141.54 & -527.37 & -14.37 & -1.55 \\
Built-up & 50.58 & 108.29 & 57.70 & 114.08 & 7.61 \\
Cloud shadow & 1068.04 & 918.51 & -149.53 & -14.00 & -1.51 \\
Water & 40.23 & 59.29 & 19.06 & 47.37 & 3.88 \\
Total & 13189.86 & $13009.07^{*}$ & & & \\
\hline
\end{tabular}

* The Landsat scenes for the two years were slightly different, hence different total land-cover area.

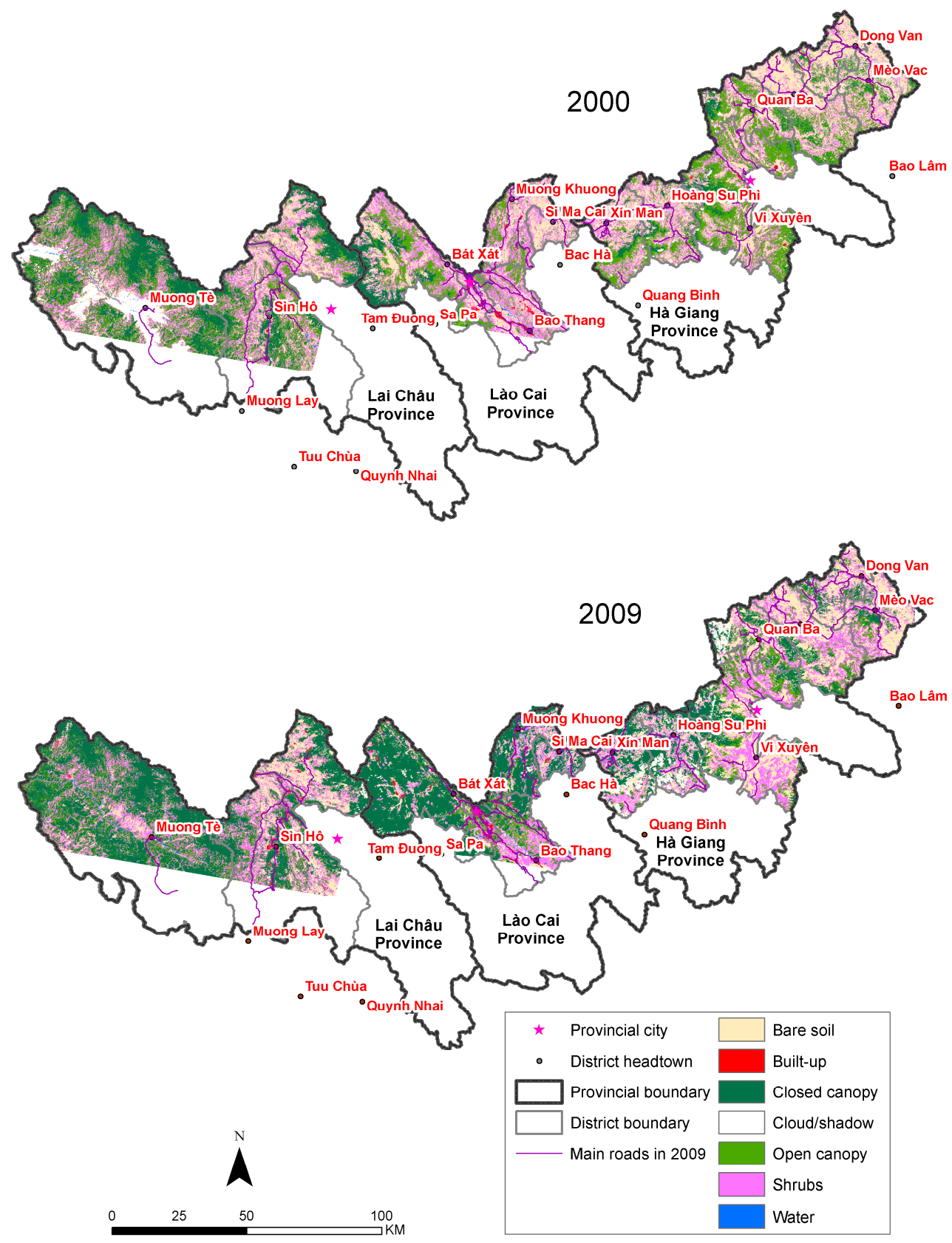

Figure 4. Land cover maps for the region, 2000 and 2009. 
Table 4. Land-cover change in the region by district $\left(\mathrm{km}^{2}\right), 2000-2009$.

\begin{tabular}{|c|c|c|c|c|c|c|c|c|c|}
\hline Province/District & $\begin{array}{l}\text { Closed } \\
\text { Canopy }\end{array}$ & $\begin{array}{c}\text { Open } \\
\text { Canopy }\end{array}$ & Shrubs & Bare Soil & Built-up & $\begin{array}{l}\text { Cloud } \\
\text { Shadow }\end{array}$ & Water & $\begin{array}{c}\text { Absolute } \\
\text { Change }\left(\mathbf{k m}^{2}\right)^{*}\end{array}$ & $\begin{array}{c}\text { Absolute Change/ } \\
\text { Total Area** } \\
\end{array}$ \\
\hline \multicolumn{10}{|l|}{ Lai Châu Province } \\
\hline Mường Tè & 503.14 & -231.83 & -30.54 & -75.52 & 3.90 & -243.95 & 7.22 & 852.15 & 0.35 \\
\hline Sìn Hồ & 93.47 & -175.11 & 14.07 & 32.50 & 17.05 & -71.93 & -2.71 & 334.90 & 0.27 \\
\hline Phong Thổ & 69.50 & -77.95 & -43.30 & 28.69 & 11.45 & 8.59 & 2.64 & 233.53 & 0.28 \\
\hline \multicolumn{10}{|l|}{ Lào Cai Province } \\
\hline Bát Xát & 571.35 & -218.24 & -234.72 & -149.47 & 13.27 & 13.07 & 4.61 & 1191.66 & 1.13 \\
\hline Lào Cai City & 71.92 & $-18.50 * * *$ & -27.74 & -47.02 & 17.76 & 0.65 & 2.94 & 185.89 & 0.87 \\
\hline Bảo Thắng & 105.41 & 22.83 & -32.25 & -88.88 & -7.94 & 0.85 & -0.31 & 257.63 & 0.49 \\
\hline Mường Khương & 313.35 & -89.74 & -121.43 & -112.09 & 6.69 & 2.91 & 0.87 & 644.18 & 1.16 \\
\hline Si Ma Cai & 91.42 & -6.96 & -18.21 & -73.69 & 5.74 & 0.26 & 1.25 & 197.27 & 0.85 \\
\hline \multicolumn{10}{|l|}{ Hà Giang Province } \\
\hline Xín Mần & 161.50 & -120.03 & -51.27 & -41.19 & 0.00 & 48.63 & 2.20 & 376.20 & 0.66 \\
\hline Hoàng Su Phì & 188.44 & -116.39 & -62.59 & -52.84 & -0.99 & 43.73 & 1.12 & 422.37 & 0.67 \\
\hline Vị Xuyên & 131.31 & -420.03 & 117.64 & 170.33 & -7.97 & 10.74 & -1.66 & 848.94 & 0.58 \\
\hline Quản Bạ & 74.81 & -119.75 & -3.97 & 11.60 & -0.35 & 36.86 & 1.28 & 211.76 & 0.39 \\
\hline Yên Minh & 22.00 & -68.72 & 94.37 & -47.10 & -0.69 & 0.00 & 0.11 & 232.98 & 0.30 \\
\hline Đồng Văn & 28.76 & -11.20 & 37.74 & -61.65 & -0.22 & -0.01 & -0.48 & 140.05 & 0.31 \\
\hline Mèo Vạc & 10.75 & -42.36 & 38.41 & -21.04 & 0.00 & 0.05 & -0.03 & 112.59 & 0.20 \\
\hline
\end{tabular}

Note: Blue italics and red bold values: important increases and decreases, respectively. ${ }^{*}$ Absolute change is the sum of absolute values of each LULCC, excluding areas covered by cloud/shadow. ${ }^{* *}$ Total areas do not include cloud/shadows. ${ }^{* * *}$ The change in open canopy class in Lào Cai city is numerically small, but was 37.83 percent of the total open canopy area in 2000.

Coverage by shrubs declined across our study region, with the exception of the eastern districts of Hà Giang (Vị Xuyên, Yên Minh, Đồng Văn, and Mèo Vạc). The most noticeable loss was in Bát Xát District, Lào Cai Province, and a close look at the transition map (Figure 5) shows this area changed mostly to closed canopy forest. Two main transitions to shrubs occurred; first, when open canopy forest converted to shrubs (in Vi Xuyên District, Hà Giang Province) and second, and more pronounced, when bare soils changed to shrubs (mostly in Yên Minh, Đồng Văn, and Mèo Vạc). It should be noted that this so-called transition from bare soils to shrubs probably reflects the confusion noted above in Section 4.2, with observations and interviews (2010) supporting the contention that very little change in areas of crop cover have occurred here. Bare soils were reduced in most districts. They changed to closed canopy forest in Mường Tè (Lai Châu Province), in west Bát Xát and Mường Khương (Lào Cai Province), and in Xin Mần and Hoàng Su Phì (Hà Giang Province). However there were some gains of bare soils in southern Hoàng Su Phì, adjacent to Vị Xuyên. Another noticeable change, although not as large in square kilometers as the aforementioned changes, was the expansion of built-up areas corresponding to urban growth in the region. This expansion occurred mostly in Sìn Hồ, Phong Thổ (Lai Châu Province), and in Bảo Thắng and Lào Cai City (Lào Cai Province) (Table 4). The most important transitions in the region are shown in Table 5 and illustrated in Figure 5.

Examining the magnitude of change versus stability in each district (Table 4, final two columns) we note some important tendencies. Districts with the highest amounts of change were Mường Tè, Bát 
Xát, Mường Khương, and Vị Xuyên, hence high rates of change are spread across the study region. When taking into account district size, Bát Xát, Lào Cai City, and Si Ma Cai were the most dynamic, all in Lào Cai Province. Inversely, the most stable districts were Sìn Hồ and Phong Thổ in Lai Châu Province, and Yên Minh, Mèo Vạc, and Đồng Văn in Hà Giang Province. Further analyses of the links between these LULCC patterns and livelihoods are explored next.

Table 5. Transitions of land-cover types in the region, 2000 to $2009\left(\mathrm{~km}^{2}\right)$.

\begin{tabular}{ccccccccccc}
\hline & & \multicolumn{7}{c}{ In 1999 } \\
\cline { 3 - 10 } & & Cloud & Water & $\begin{array}{c}\text { Closed } \\
\text { Canopy }\end{array}$ & $\begin{array}{c}\text { Open } \\
\text { Canopy }\end{array}$ & Shrubs & Bare Soil & Built-up & Total \\
\hline \multirow{2}{*}{ Shadow } & Cloud shadow & 506.81 & 1.52 & 110.40 & 142.63 & 93.13 & 61.92 & 0.87 & 917.28 \\
& Water & 8.51 & 15.45 & 1.68 & 3.86 & 8.41 & 19.70 & 1.82 & 59.45 \\
\multirow{2}{*}{ In } & Closed canopy & 139.74 & 0.97 & 1285.01 & $\mathbf{1 3 4 4 . 6 3}$ & $\mathbf{8 7 1 . 1 0}$ & $\mathbf{5 1 5 . 5 0}$ & 1.66 & 4158.61 \\
& Open canopy & 98.04 & 1.73 & 115.34 & 650.42 & 472.50 & 245.52 & 3.21 & 1586.76 \\
& Shrubs & 103.44 & 4.30 & 87.95 & $\mathbf{6 6 2 . 1 5}$ & 1155.14 & $\mathbf{1 0 0 5 . 8 8}$ & 13.39 & 3032.25 \\
& Bare soil & 66.78 & 14.72 & 114.72 & $\mathbf{4 5 6 . 6 9}$ & $\mathbf{7 2 3 . 5 7}$ & 1744.98 & 18.33 & 3139.79 \\
& Built-up & 2.58 & 1.61 & 0.98 & 6.08 & $\mathbf{2 4 . 6 6}$ & $\mathbf{6 1 . 0 6}$ & 11.29 & 108.27 \\
& Total & 925.90 & 40.31 & 1716.09 & 3266.45 & 3348.51 & 3654.56 & 50.58 & 13002.40 \\
\hline
\end{tabular}

Note: Grey cells indicate amount of land-cover type that has not changed, bold numbers indicate important changes.

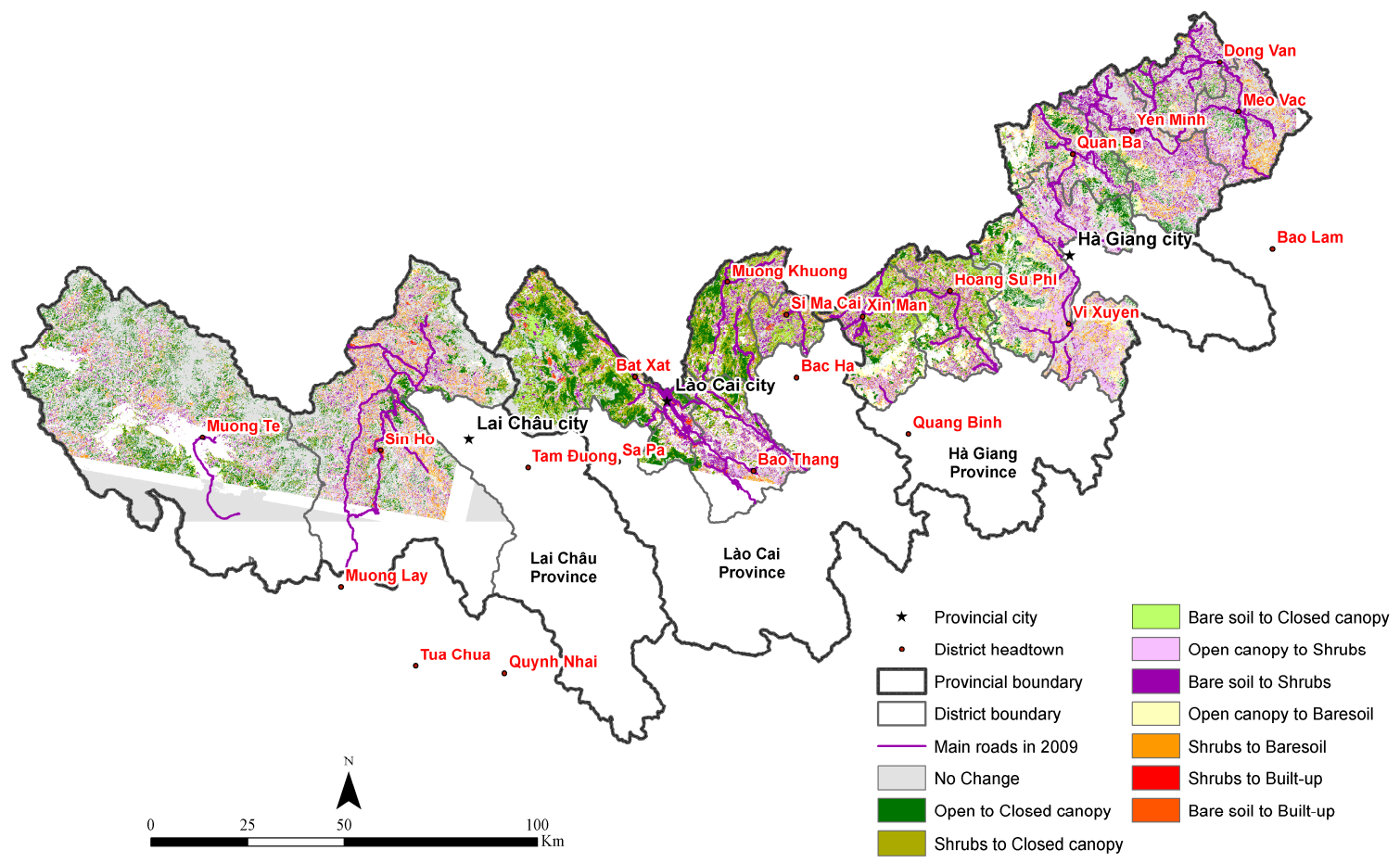

Figure 5. Transitions of land-cover types in the region between 2000 and 2009.

\subsection{Examining the Underlying Relationships between LULCC and Livelihood Diversification}

Drawing on our quantitative findings above, in this section we focus on three case studies, one from each of our study provinces. Specific case studies cannot represent the entire spectrum of change across these uplands, and our cases were chosen instead to highlight the breadth of LULCC types 
underway, the diversity of causes, some important impacts on local livelihoods, livelihood diversification responses, and some surprise findings.

\subsubsection{Urbanization in the Uplands and the Case of Lai Châu's Changing Capitals}

Across our study site there was a 114 percent increase in built-up areas, notably in Sìn Hồ and Phong Thổ (Lai Châu Province), as well as in Bát Xát, Lào Cai City, and Bảo Thắng (Lào Cai Province). Over half of this expansion transpired in the Red River valley, within the city municipality of Lào Cai, and to its immediate west in Bát Xát District. This increase is concurrent with national strategies to encourage cross-border trade and to stimulate the Greater Mekong Subregion North-South Economic corridor, begun in 1998. The Vietnamese government is investing heavily in Lào Cai City and its environs, supporting trade and improving road infrastructure. This has included the creation or upgrading of border crossing points for heavy vehicles carrying merchandise from both Bát Xát District and Lào Cai City to and from Yunnan, China. At the provincial level, the 2020 Lào Cai Economic Development Plan continues to prioritize construction, renovation, and improvement of facilities at the Lào Cai-Hekou (Yunnan) border crossing, as well as the construction of new, smaller border crossings [78].

Livelihood opportunities have undergone notable diversification in Lào Cai City. In 1999 this was a sleepy, dusty frontier town with most activity focused on the border crossing with Hekou Town, Yunnan. By 2009, the metropolises on both sides of the border had expanded considerably, with Lào Cai City boasting a new six-story border gate administrative center and a brand new multi-story shopping center. The city's main marketplace was also renovated and expanded, selling numerous electronics and plastic goods imported from China. As one Kinh trader noted, sweeping her hands over her stall's plastic toys: "All of this, I get it all from China" (interview, August 2013). While these expanding trades and services have provided new livelihood opportunities, it is important to note that overwhelmingly, it is ethnic Kinh (Vietnamese lowlanders) who have taken up employment opportunities here, rather than ethnic minorities from the surrounding countryside. Without the formal education skills, social capital, and financial reserves necessary to enter urban livelihoods, upland urbanization has remained strongly ethnically divided. When asked why they do not move to Lào Cai City for work opportunities, a group of Hmong ethnic minority young women responded, "Why would we go there? It's scary — close to the border we might get kidnapped, and we don't want to work in the city anyhow. Our home is here" (interviews, January 2009; July 2014). ${ }^{2}$ As such, young ethnic minority men and women tend to remain based in rural villages - either that of their parents or, for women after marriage, that of their husband - and maintain agricultural livelihoods, plus small-scale trade for some. While there is migration of ethnic minority individuals over the border for agricultural or mining labor, this remains strongly gender-divided for men only and is limited in size. This urbanrural ethnic divide is also apparent elsewhere in our study region, in Lai Châu and Hà Giang cities.

Growth in built-up areas in these borderlands is also due to the establishment of new administrative districts, and thus the need for new head towns. This transformation occurred in August 2000 for Si

\footnotetext{
${ }^{2}$ An increasing number of young ethnic minority women have been trafficked to China to become wives for rural farmers there. A common kidnapping approach is for a young man - often from the same ethnicity and posing as a friend of a friend - to lure a young woman to Lào Cai City on his motorbike 'to have fun'; she is then abducted and taken over the border (interviews with Hmong and Yao youth, 2009, 2014).
} 
Ma Cai Town, which became the head town of a new district with the same name in the east of Lào Cai Province [79]. This resulted in a new suite of roads, public services, and administrative buildings [80], plus all the officials who go with such a bureaucracy. Locals whom we talked to in Si Ma Cai, who had lost their land to these new infrastructure developments, were none too pleased with the limited compensation (interviews, March 2009).

The cause of built-up areas in Lai Châu Province, the farthest west of our study provinces, is perhaps even more controversial. Here, urban "upgrading" has also occurred, but this time largely due to the creation of a large reservoir for a dam project further south in Sorn La Province (see Figure 1 for the dam's location). Lai Châu Province consists of Lai Châu City and seven districts (with the most recent, Nậm Nhùn, created in 2012) with a combined total of 98 communes [81]. The province's total land area is 9,112.3 square kilometers [82]. The province is considerably smaller than it used to be, however, as a new province called Điện Biên was created to the west of Lai Châu province in 2004, carving off Lai Châu Province's more industrialized and financially prosperous southern and western parts $[48,83]$. To the south of Lai Châu Province, construction began on the Sơn La dam in 2005; when it was completed in 2012, it was the largest hydropower plant in Southeast Asia, with a $224 \mathrm{~km}^{2}$ reservoir [84]. The project required the displacement of over 91,000 ethnic minority individuals across three provinces, including Lai Châu Province, beginning in 2005 [85]. In Lai Châu, the resettlement of certain villages was delayed because of conflicts over land prices and an absence of infrastructure at resettlement sites [84]. These sites are mostly in rural areas and with resettlement being fairly recent, their impacts were not clear on our LULCC maps, although resettlement villages are now observable in the high-resolution imagery used by Google Earth.

Just south of our study area, it has been intriguing to observe the increase in urban land use around the newly relocated provincial capital, also called Lai Châu, inaugurated with its new name in 2004 [86]. Formerly a sleepy town called Phong Thổ, the "new Lai Châu" was given a substantial makeover to become the new provincial capital because the former Lai Châu Town was lost to the dam's reservoir. ${ }^{3}$ Extensive new infrastructure including large government offices and wide boulevards were already complete by 2006 - when we observed the roads being used for motorbike racing and not much else - and "new Lai Châu" was formally recognized as having gained "city status" in December 2013 [87]. By 2014, the total urban area of this new city was more than 7,000 ha with 52,500 residents and seven wards [87].

Back within our study site's border districts in Lai Châu Province, the most important growth of built-up areas — an increase of $17 \mathrm{~km}^{2}$ - has occurred in a linear fashion along Road 12, which crosses the district of Sìn Hồ from north to south (Figure 6). This increase is on par with the urban growth around Lào Cai City, in Lào Cai Province. While most interviewees suggested this growth was due to local household livelihoods diversifying into new, small-scale trade possibilities along the road as traffic (and tourism) increases with improved roads, some of this urban growth might also be due to resettlement from the dam. Only two interviewees of the 10 with whom we talked along Road 12 had moved to this area due to dam resettlement, but it would not surprise us if others had also done so.

\footnotetext{
${ }^{3}$ In 2004-2005, when former Lai Châu Province was split into Lai Châu and Điện Biên, former Lai Châu Town was renamed Mường Lay Town, now part of the new province of Điện Biên. Most of this town is now under the reservoir for the Sơn La dam.
} 
These changes require further investigation as uncertainty also surrounds a new hydroelectric project, the Lai Châu dam, this time in the province itself (Nậm Hang Commune, Mường Tè District), which will be the third largest in the country after the Hoà Bình and Sơn La projects, also on the Đà River. The Lai Châu dam was initiated in 2011, was 80 percent completed in 2014, and is expected to be operational by 2017. This project alone requires the relocation of approximately 800 rural households [88] and may bring important LULCC to Mường Tè District and, in turn, changes in possible livelihoods.

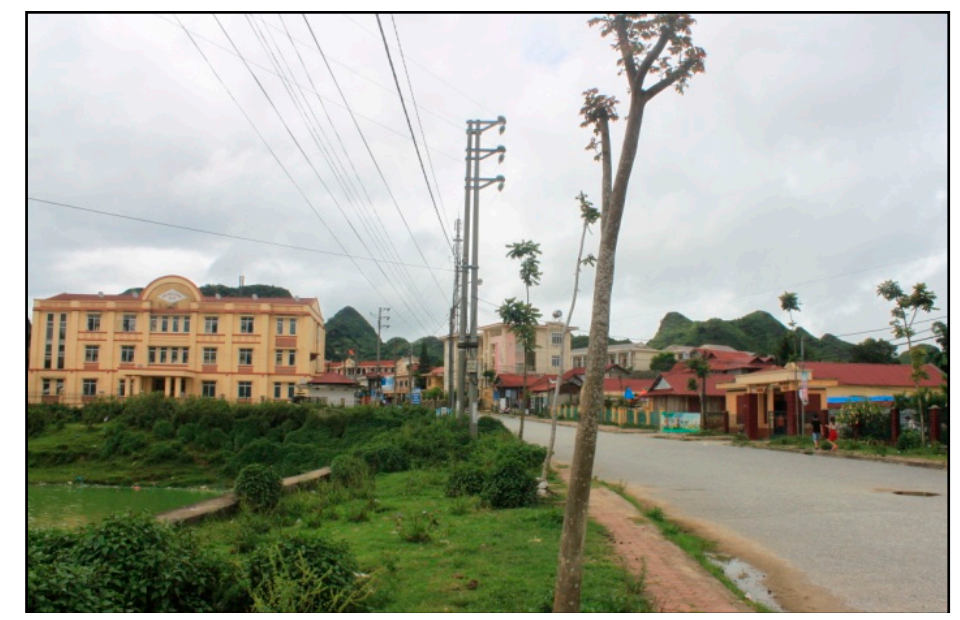

Figure 6. Sìn Hồ Town on Road 12. (Photo credit: Lê Mạnh An)

\subsubsection{The Impacts of Increased Cash Needs on Closed Canopy Forest: The Case of Bát Xát District}

In terms of LULCC in rural areas of our study region, there was a total increase of $531 \mathrm{~km}^{2}$ in closed canopy forest (over 300 percent). This is in line with a national study that also concluded that the extent of the forest network increased during this time period (though it did not note density, diversity, or quality) [70]. Our findings show that most forest change happened in Bát Xát and Mường Khương Districts (Lào Cai Province), Mường Tè (Lai Châu Province), and Hoàng Su Phì and Xín Mần (Hà Giang Province).

Lào Cai Province lies in the center of our three study provinces. It is divided into eight administrative districts with a combined total of 164 communes, plus Lào Cai City. The province's total land area is 6,383.9 square kilometers [82]. In the west of Lào Cai Province, Bát Xát District is characterized by high elevations and steep slopes, a sparse road network, and relatively few marketplaces. With a population of approximately 70,000, the dominant ethnic group in the district is Hmong (approx. 26 percent) [48,89]. In 1999, this region was principally classified as upland fields, identified as bare soil in our maps, with dry rice and maize production. From our interviews with Hmong and Yao uplanders here, we found that a transition towards state-sponsored high-yield hybrid rice had taken place alongside a decrease in upland fields/bare soils; the total decrease in agricultural land being nearly $150 \mathrm{~km}^{2}$, or 54 percent of the district. Interviewees explained that many farmers had chosen to begin using intensive rice farming techniques as the state discouraged swidden agriculture with dry rice and maize. As one Hmong interviewee in Mường Hum, a market town within Bát Xát District, put it, "The corn and the dry rice, we had to stop" (August 2013). While reducing the land used for agriculture, this switch has had important repercussions for livelihood strategies, as farmers are now obliged to purchase (infertile) hybrid rice and 
maize seeds annually as well as chemical pesticides and fertilizers. Another Hmong farmer explained, "We need to buy the seeds every year now, rather than saving some, because the Chinese [hybrid] seeds are not so good to save" (March 2007). As a result, semi-subsistence households are far more dependent on the cash economy than in the past (interviews 2004, 2007, 2013, see also [26]).

Interviews with minority farmers in the district suggest that the increase in forest cover in Bát Xát District (one of the most dynamic districts across our fieldwork sites; see Table 4) could be the result of a declining agricultural footprint, reforestation policies, and an increase in cardamom cultivation to meet the increasing cash needs of local households (interviews 2013). Highly sought after in China, cardamom grows in the shade of mature trees and requires relatively little labor to cultivate [90] (Figure 7). In Bát Xát District, ethnic minority farmers are increasing the amount of cardamom they cultivate to earn cash income, with some farmers recently reporting an annual harvest of $500 \mathrm{~kg}$ from their cardamom plots if the weather is good and noting, "There's far, far more [cardamom] than ten years ago" (interview, August 2013). From Bát Xát, the cardamom is transported across the border at nearby local level crossings by the farmers themselves or by Kinh intermediaries who purchase it at the "farm gate" and transport it to Lào Cai City, where most often it is collected by Chinese wholesalers. The cardamom then makes its way to wholesale markets and processing plants in Kunming, the capital of Yunnan Province, or in neighboring Guangxi Province to satisfy the sizeable demand across China (interviews 2013, 2015).

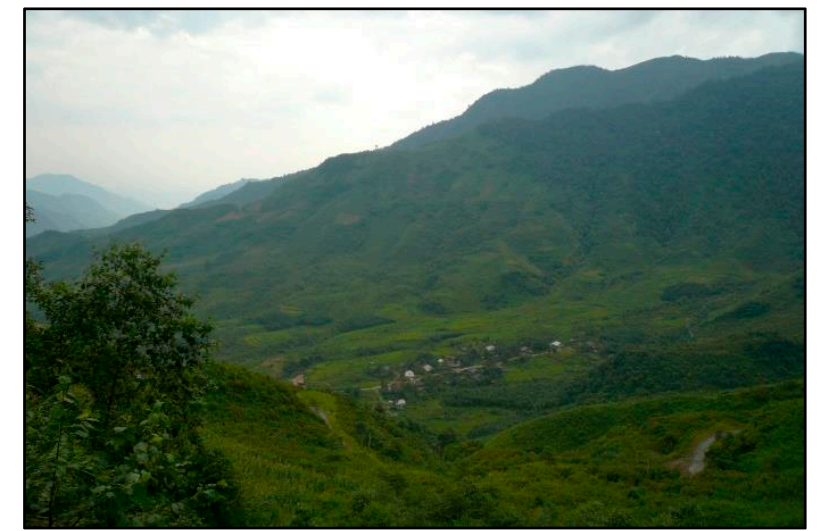

(a)

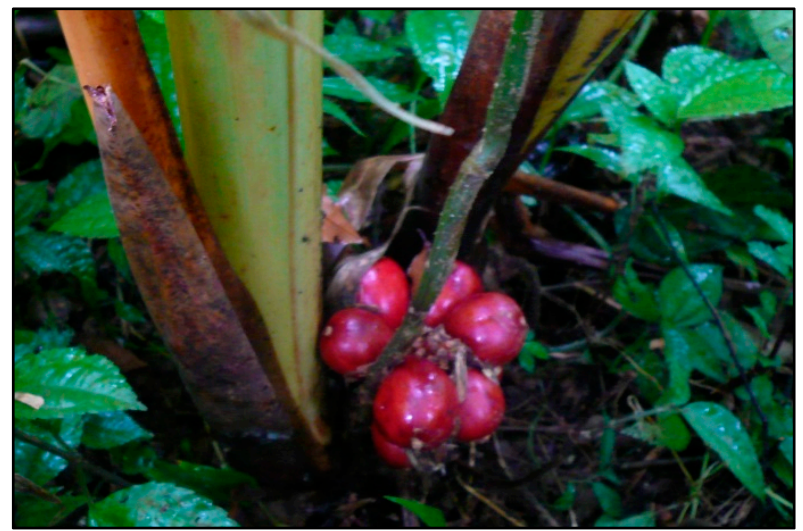

(b)

Figure 7. (a) Forest containing cardamom fields above a Hmong hamlet and (b) cardamom growing in the shade of mature trees Bát Xát District, Lao Cai Province. (Photo credit: Sarah Turner).

As the Vietnamese state attempts to homogenize agriculture in the uplands using hybrid varieties, and as demand for cash income among local farmers consequently rises, ethnic minority households are reacting by supporting reforestation through the protection and restoration of old growth forests for cardamom cultivation. Surprisingly, therefore, market integration and agrarian change have led to forest conservation and expansion in a rather roundabout way. Nonetheless, it is not clear how long this situation will continue. Despite the cash income that cardamom can bring, the increasing frequency of extreme weather events - especially extreme cold and hail storms - is resulting in unpredictable cardamom yields and unstable incomes for farmers, with one noting fluctuations of 60 to 400 kilograms a year (interviews, August 2013, June 2014). Additionally, prices fluctuate substantially from one year to 
the next, in part due to varying demand in China and in part due to volatile relationships between individual intermediary traders and cultivators, who tend to be of different ethnicities (interviews 2013) [15].

\subsubsection{When Geomorphology Tests Livelihood Limits: Đồng Văn District, Hà Giang Province}

The three districts with the least LULCC are the karst hill and mountain-peaked districts of Sìn Hồ and Phong Thổ (Lai Châu Province), and Đồng Văn and Mèo Vạc (Hà Giang Province). Here, the ratio of change is the lowest, between 0.20 and 0.30 (Table 4). To explain this lack of LULCC, we focus on the case of Đồng Văn and Mèo Vạc in Hà Giang Province. Hà Giang, the farthest east of our study provinces, is divided into 10 administrative districts with a combined total of 195 communes, plus Hà Giang Town; its total land area is 7945.8 square kilometers [82]. The province spans three officially recognized distinct agro-ecological zones. The northern borderland districts of Mèo Vạc, Đồng Văn, and Quản Bạ, within our case study, are in Zone 1. This is a reasonably homogenous high plateau agro-ecological zone. About 90 percent of the surface area is limestone, reflecting the region's karst geography. This zone supports the cultivation of maize, often on steep slopes, and the raising of livestock, mostly cattle, horses, goats, and poultry. Zone 1 also includes Yên Minh District, which is somewhat different, having large areas of open land both with and without forest cover. Zone 2 covers the mountainous western borderland districts of Hoàng Su Phì and Xín Mần, also in our case study. This zone has an average elevation of 1,600 meters, many steep slopes, and poor soil. Agriculture includes rice and maize, cash crops such as tea, and livestock rearing. Zone 3 includes Hà Giang Town as well as the districts of Bắc Mê, Bắc Quang and Vị Xuyên, which fall outside this study. These are less mountainous (500 to 1,000 meters), with old forests and valleys alternating with rivers and large streams (interviews and observations 2009, 2010) [91].

On our LULCC maps, the northernmost districts of Đồng Văn and Mèo Vạc recorded important areas of bare soil $\left(234.5 \mathrm{~km}^{2}\right.$ and $285 \mathrm{~km}^{2}$ in 2009 , or roughly 50 percent of the total area in both districts). Particularly interesting in these two districts are the ways by which local ethnic minority farmers maintain livelihoods, as these bare soils on the maps represent a specific karst landscape with extremely small pockets of usable soil just a few meters square between large numbers of rocky outcrops. In these small pockets, minority farmers have diligently added soil and traditional fertilizers (a mix of household fire ash and cattle dung) to be able to grow traditional local maize. Running up the stalks of the maize are beans, and other vegetables such as pumpkins are sometimes interspersed among these (Figure 8).

As noted earlier, across much of the upland northern provinces - and indeed elsewhere in Vietnam - farmers are being strongly encouraged by the government to switch to hybrid varieties of rice and maize seeds to increase outputs. A Yao farmer in Đồng Văn market explained, "We have to spend 3 million VND on fertilizer for the hybrid corn seeds. I get it in advance from the government and pay them back with some of my crop. Each year I have to buy new seeds" (June 2010). Our research and that of our former graduate students has shown that these crops can actually increase food insecurity in these uplands rather than improve it, due to the agro-ecological limits of the new seeds, difficulties with the appropriate quantity of seeds being supplied, and (un)timely distribution [26,92].

Notably, hybrid maize is not grown in the small pockets of land in Mèo Vạc and Đồng Văn's karst landscape because farmers insist it requires a more level growing surface. This points to the 
importance of landraces and traditional ecological knowledge for maintaining livelihoods here. Local maize diversity is maintained by traditional seed-saving within households, as well as exchange among households [92]. Hmong farmer interviewees noted that they far prefer traditional maize to hybrids due to its suitability in the rugged topography and the means by which farmers can intercrop it - this is more difficult or impossible with hybrid maize, which is planted closer together. Traditional maize also has superior long-term storage properties, being less susceptible to mold, and was declared by numerous interviewees to taste far better. As noted earlier, it should be remembered that in Table 4, the increase and decrease in bare soil and shrubs in these districts might counter-balance each other to some degree, given the results of the confusion matrix and interviews confirming very little change in land uses. Overall, when considering bare soil and shrubs together, these districts have remained extremely stable in land-cover and land-use types compared to other areas of our case study. We interpret this as being due to a harsh terrain that is not conducive to the diversification of local livelihoods away from traditional, carefully adapted land uses.

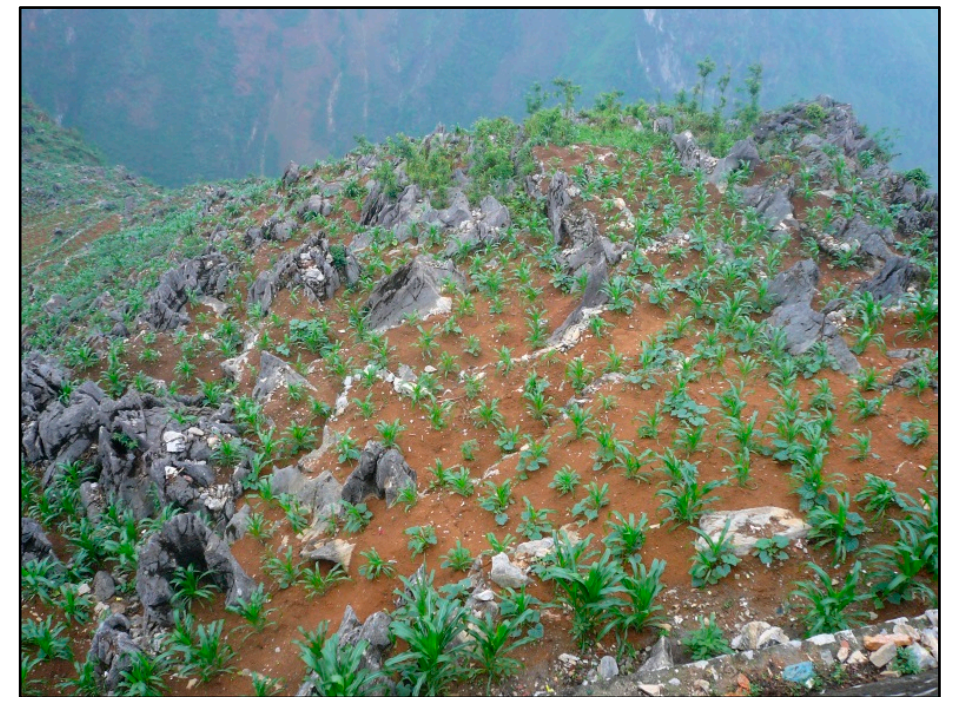

(a)

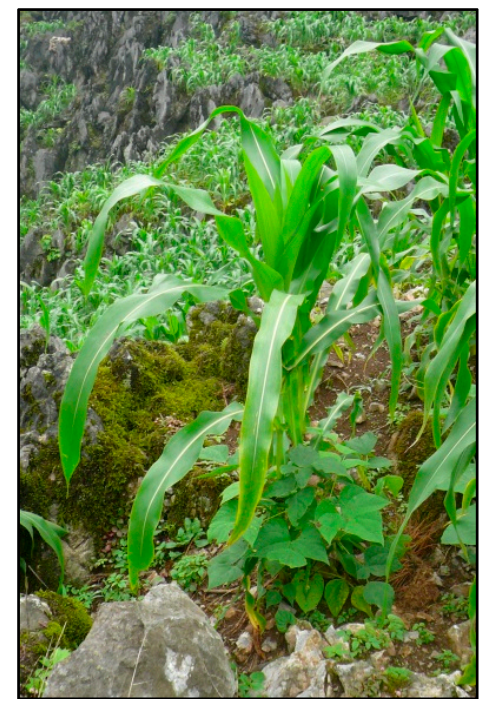

(b)

Figure 8. (a) Typical small fields with numerous karst outcrops, and (b) local maize with runner beans, Đồng Văn District, Hà Giang Province. (Photo credit: Sarah Turner).

\section{Discussion: Market Integration, State Policies, and Land-Use Change}

In general, land uses in our frontier study region are undergoing substantial and often conflicting transformations. In one interview, a forest ranger noted, "They [the state] are razing the mountains," in relation to new hydropower dam projects and recently built urban areas in Lào Cai Province, both reflecting the modernization drive of state and private actors in this frontier zone. Yet elsewhere in the same province, another ranger said, "Look at the hills there. I planted and protected them, those hills and forest there. I worked six to seven years there. People understand, they dare not burn forest to make new fields," reflecting an awareness (corroborated by local farmers) of the importance of forests for local watershed protection. Not only our interviews but also our maps demonstrated a complex LULCC picture. In some areas, forests were expanding, while in others they were declining; in yet others they remained remarkably stable due to the agro-ecological limits of the local geology, but what 
are the underlying causes of LULCC in this region? How are livelihood strategies related to these highly variable dynamics of land use across this upland border region?

During the last 25 years, upland northern Vietnam has been considered a frontier region by the state, a region to be modernized and civilized as rapidly as possible [93]. The 2013 Vietnam Constitution promotes "cultural development" (phát triển văn hóa), and "social progressiveness" (tiến bộ) while focusing on the "modernization" (hiện đại hóa) of the country [94]. The northern uplands are the focus of numerous policies that have drawn on these principles and concurrently have substantively challenged or changed the livelihoods and livelihood diversification strategies of ethnic minorities $[2,3,68,90,95]$. Infrastructure to encourage upland integration increased considerably between 1999 and 2009, marked by an expanded road network that reduced distances to marketplaces newly renovated by the state and connected upland and lowland towns and cities. Such infrastructure has created additional livelihood opportunities for local households to sell agricultural surpluses, gain access to market knowledge or resources, and acquire non-agricultural income [96]. Yet other state-driven interventions and marketoriented economic reforms, including the introduction of and strong state support for hybrid rice and maize seeds, have rarely favored ethnic minorities' indigenous knowledge and historical land uses, but instead have frequently challenged their land-use strategies, often with negative impacts on food security [3,26,45,97].

Ongoing state-supported "development" projects in these borderlands trigger multidimensional responses from local populations that face challenges accessing livelihood resources or who are confronted with the state's vision of what their livelihoods should be (resettled, based on hybrid crops, cash-based, and so on). In our study locale, many rural upland residents have maintained composite agricultural systems as their primary livelihoods, rather than transitioning to plantation crops such as coffee or rubber that are often (but not always) grown on a larger scale [98]. Instead, livelihood diversification has occurred in these borderlands for a range of other complex reasons. The state's drive for farmers to use hybrid rice and maize seeds, for instance, means farmers must have access to more cash for inputs than ever before. In turn, some individuals with the human capital-appropriate skills and know how - and access, have chosen to cultivate cardamom under the shade of closed canopy trees. Providing cash income in this way, farmers have let go of some of their former hillside swidden agricultural lands to focus on hybrid seed crops; in turn, forest cover is increasing. While this livelihood diversification approach and chain of events is a surprising avenue for forest cover regeneration, resulting in a specific LULCC, less surprising is the urban development occurring along the Red River, as again the state intervenes in frontier "development". This time, pushing for greater market integration via inclusion in the Greater Mekong Subregion, the state has heavily promoted urbanization and industrialization adjacent to the Lào Cai-Hekou border crossing, with imports and exports rising steadily (trade data shows the value of goods traded across this border crossing rose from US\$92 million to US\$993 million from 2000 to 2011 [99]). Urban livelihood opportunities here have diversified dramatically for Kinh residents and traders as this frontier city expands, and an ever-increasing range of goods and services has become available. The complexity of this region is again highlighted with the contrasting tale of eastern Hà Giang Province, where ethnic minority farmers have worked within fairly constraining agro-ecological limits to maintain livelihoods that are diverse within themselves, but yet have remained extremely stable over time. This stability has been reflected in the near lack of LULCC in the most north-eastern districts. 


\section{Conclusions}

State policies for this frontier region, market opportunities (both state-supported and private), and agro-ecological conditions have resulted in highly complex and heterogeneous land uses and land covers. Yet can LULCC mapping really help us to unravel these changes? While completing this project we hit many roadblocks. Mapping LULCC in the mountainous regions of Vietnam is challenging, not only due to the political and physical complexities of accessing the field, but also due to a lack of fine-scale spatial data. Landsat images are the most available data, but the resolution is not fine enough to distinguish bare soils from built-up areas, shrubs from planted crops, and various crops from each other. We found many interesting tales on the ground of livelihood diversification at a scale the maps could not register. For instance, Hmong farmers in Mường Khương District, Lào Cai Province have been experimenting with pineapple plantations, bringing inputs (pineapple plants) and crop-cultivation skills with them from former employment in plantations just over the border in China. Will such crop diversification change land cover in important ways in this area? Others in Mèo Vạc District, Hà Giang Province have been experimenting with honey production and sales to Hanoi distributors, with beehives kept in forests near specific trees to produce highly desired flavored honey. Could honey be the new cardamom and start to protect (the limited) forests there? Only time will tell. As such, the interpretation of LULCC maps must be done with caution and be combined with in-depth, on-theground knowledge.

Nonetheless, at the same time, the LULCC maps we developed allowed us to take a step back from our ethnographic results and place them within the bigger picture. We knew that cardamom was an increasingly important crop for many ethnic minority livelihoods, but we needed to see these maps to begin to realize that there were dramatic changes occurring to forest cover that seemed to be connected. This motivated us to return to local villages and ask the relevant questions to confirm these causal links. Likewise, we knew of livelihood constraints in Hà Giang Province, but not the degree to which land-use types are static at the district level over time, proving that the state really does reach limits in trying to push specific agricultural policies. The numerous urban growth patterns across the region are noticeable as one drives through these built-up areas, but the causes of their growth became easier to deconstruct while examining the bigger picture. Although not part of this paper, our findings regarding urban change have stimulated us to start a new project examining the growth of small cities and towns in these uplands with a focus on how LULCC is occurring in peri-urban zones, the quality of life that local residents enjoy, and rural-urban migration processes.

Our mixed methods approach, drawing on an interactive design, provided scope for raw data to be examined and re-examined in an iterative process, moving back and forth between quantitative and qualitative results so as to socialize the pixel as well as pixelize the social [100]. Moreover, a conceptual framework drawing on land change science, frontier studies, and livelihood diversification literature allowed for the integration and recognition of a number of important variables across multiple scales. These ranged from frontier transformation and resource exploitation projects (hydropower dams, hybrid seed programs, urban infrastructure), to culturally-rooted livelihood diversification decisions (specific knowledges of agro-ecological limits, watershed needs, non-timber forest product responses to extreme weather events, and so on). We also found that a key benefit of a mixed methods approach emerged from the justifications and explanations we had to provide to each other regarding our contributions. The first 
author was forced to find answers beyond the household and village levels regarding processes she had previously most often examined at the micro-scale, and then be able to defend her arguments. Likewise, the second author found that she needed to justify and explain meso-scale results to the first author, who required convincing of the percentage changes that had been calculated. We constantly went back to check our fieldwork notes, examine the data again, and tighten our arguments. While all researchers should do this, of course, our different methodological perspectives and assumptions had to be explained and "typical findings" defended. We believe that this cyclical verification added further strength to our results. Our study thus contributes to the emerging trend of using grounded, in-depth fieldwork to help explain regional land change [17,101], while also shedding light on the benefits meso-scale studies can bring to micro-scale ethnographies.

Our findings point to the importance of policy makers having access to complementary methods and an integrated conceptual framework for implementing appropriate, sustainable land-use and livelihood policies in the region. Yet, at the same time, many upland residents may not be that receptive to state officials asking them probing questions regarding their land uses and livelihoods: farmers are sometimes cultivating cardamom within national parks where doing so is illegal; those being strongly encouraged to plant hybrid rice and maize often prefer to covertly maintain a more diverse livelihood approach that they know will work within local agro-ecological limits; and urban growth in this frontier locale includes illegal (smuggling, prostitution, trafficking, etc.) as well as legal livelihood opportunities. Perhaps this points to an important bridging role for non-state researchers here [102]. Nonetheless, if officials are sympathetic to local resident concerns over livelihood opportunities, greater knowledge of LULCC and livelihoods in this region could also forge important opportunities. For instance, officials recognizing an increase in closed canopy forest on a LULC map could encourage the regulated cultivation of cardamom with strict firewood rules (for drying the pods) and set harvest dates to help protect forests, as has been implemented with success just over the border in Yunnan (interviews 2015). Likewise, greater awareness of agro-ecological limits - noting the lack of change in certain areas in LULCC tables and maps - could mean that unsustainable agricultural policy options are rejected. Instead, the traditional ecological knowledge of upland farmers could be acknowledged and taken on board, as is beginning to occur in lowland regions regarding the limits of hybrid seeds [103].

The question then turns to how to incorporate such findings into decision-making processes. With an extremely hierarchical state apparatus, this is not a particularly easy task in Vietnam [102,104]. We recommend a diverse approach, making the most of opportunities to collaborate with local academics such as members of the North-West Research Program at Vietnam National University (Hanoi), discussing findings at public conferences in the country and regionally, and contributing to meetings such as those held by the Ethnic Minority Working Group supported by the Non-Governmental Organization (NGO) Resource Centre in Hanoi. Through numerous discussions and collaborations it is hoped that greater awareness among policy makers and NGOs of these layers of LULCC complexity can effectively advance relevant research and culturally aware policies for appropriate household strategies and livelihood diversification across the uplands. 


\section{Acknowledgments}

We would like to thank Lê Mạnh An for fieldwork assistance, Melody Lynch, Thomas Kettig, and Kate Trincsi for research assistance, and special issue editors, Claudia Radel and Jackie Vadjunec, for feedback on an earlier draft. We acknowledge funding from the Social Sciences and Humanities Research Council, Canada.

\section{Author Contributions}

Pham completed the remote sensing data analysis and initial interpretations; Turner completed the ethnographic data analysis and interpretations. Turner drafted the context and conceptual framework, with input from Pham. Using a mixed methods approach, explained in the paper, both authors worked together to explore emerging interpretations and themes from the combined data. Both authors contributed equally to the final paper in an iterative process.

\section{Conflicts of Interest}

The authors declare no conflict of interest.

\section{References}

1. Fox, J.; Rindfuss, R.R.; Walsh, S.J.; Mishra, V. People and the Environment: Approaches for Linking Household and Community Surveys to Remote Sensing and GIS; Kluwer Academic: Boston, MA, USA, 2003.

2. Castella, J.-C.; Manh, P.H.; Kam,S.P.; Villano, L.; Tronche, N.R. Analysis of village accessibility and its impact on land use dynamics in a mountainous province of northern Vietnam. Appl. Geogr. 2005, 25, 308-326.

3. Jakobsen, J.; Rasmussen, K.; Leisz, S.; Folving, R.; Quang, N.V. The effects of land tenure policy on rural livelihoods and food sufficiency in the upland village of Que, North Central Vietnam. Agric. Syst. 2007, 94, 309-319.

4. Chi, V.K.; van Rompaey, A.; Govers, G.; Vanacker, V.; Schmook, B.; Hieu, N. Land transitions in northwest Vietnam: An integrated analysis of biophysical and socio-cultural factors. Hum. Ecol. 2013, 41, 37-50.

5. Jadin, I.; Vanacker, V.; Hoang, H.T.T. Drivers of forest cover dynamics in smallholder farming systems: The case of northwestern Vietnam. Ambio 2013, 42, 344-356.

6. Lambin, E.F.; Meyfroidt, P. Land use transitions: Socio-ecological feedback versus socio-economic change. Land Use Policy 2010, 27, 108-118.

7. Chhabra, A.; Geist, H.; Houghton, R.A.; Haberl, H.; Braimoh, A.K.; Vlek, P.L.G.; Patz, J.; Xu, J.; Ramankutty, N.; Coomes, O.; Lambin, E.F. Multiple impacts of Land use/cover change. In Land Use and Land Cover Change: Local Processes and Global Impacts; Geist, H., Lambin, E., Eds.; Springer: Berlin, Germany, 2006; pp. 71-116.

8. Xu, J.; Fox, J.; Melick, D.; Fujita, Y.; Jintrawet, A.; Jie, Q.; Thomas, D.; Weyerhaeuser, H. Land use transition, livelihoods, and environmental services in Montane Mainland Southeast Asia. Mt. Res. Dev. 2006, 26, 278-284. 
9. Aspinall, R.J.; Hill, M.J. Land Use Change: Science, Policy and Management; CRC Press: Boca Raton, FL, USA, 2008.

10. Makalle, A.M.P.; Obando, J.; Bamutaze, Y. Effects of land use practices on livelihoods in the transboundary sub-catchments of the Lake Victoria Basin. Afr. J. Environ. Sci. Technol. 2008, 2, 309-317.

11. Scott, J. The Art of Not Being Governed: An Anarchist History of Upland Southeast Asia; Yale University Press: New Haven, CT, USA, 2009.

12. Glassman, J. Bounding the Mekong: The Asian Development Bank, China, and Thailand; University of Hawai'i Press: Honolulu, HI, USA, 2010.

13. Turner, S. Under the state's gaze: Upland trading-scapes on the Sino-Vietnamese border. Singap. J. Trop. Geogr. 2013, 34, 9-24.

14. Trincsi, K.; Hien, P.T.T.; Turner, S. Between state-led policies and mountains: Land use land cover change of ethnic minorities in Vietnam's borderlands. Land Use Policy 2014, 41, 484-497.

15. Turner, S.; Bonnin, C.; Michaud J. Frontier Livelihoods. Hmong in the Sino-Vietnamese Borderlands; University of Washington Press: Seattle, WA, USA, 2015.

16. Douglass, M.; DiGregorio, M.; Bunjamin, W.; Pichaya, V.; Taniguchi, K. Poverty: From basic needs to entitlements in Vietnam during urban transition. In New Challenges for Sustainable Development in Millennia; Liu, C.H., Yeh, J.-R., Huang, C.-H., Eds.; CIER Press: Taipei, Taiwan, 2003; pp. 127-174.

17. Brannstrom, C.; Vadjunec, J.M. Notes for avoiding a missed opportunity in sustainability science: Integrating land change science and political ecology. In Land Change Science, Political Ecology, and Sustainability; Brannstrom, C., Vadjunec, J.M., Eds.; Routledge: London, UK, 2013; pp. 1-23.

18. Gutman, G.; Janetos, A.C.; Justice, C.O.; Moran, E.F.; Mustard, J.F.; Rindfuss, R.R.; Skole, D.; Turner, B.L., II; Cochrane, M.A. Land Change Science Observing, Monitoring and Understanding Trajectories of Change on the Earth's Surface; Kluwer Academic: Dordrecht, The Netherlands, 2004.

19. Rindfuss, R.R.; Walsh, S.J.; Turner, B.L., II; Fox, J.; Mishra, V. Developing a science of land change: Challenges and methodological issues. Proc. Natl. Acad. Sci. USA 2004, 101, 13976-13981.

20. Turner, B.L., II; Lambin, E.F.; Reenberg, A. The emergence of land change science for global environmental change and sustainability. Proc. Natl. Acad. Sci. USA 2007, 104, 20666-20671.

21. Geist, H.J.; Lambin, E.F. Proximate causes and underlying driving forces of tropical deforestation: Tropical forests are disappearing as the result of many pressures, both local and regional, acting in various combinations in different geographical locations. BioScience 2002, $52,143-150$.

22. López-Carr, D.; Davis, J.; Jankowska, M.M.; Grant, L.; López-Carr, A.C.; Clark, M. Space versus place in complex human-natural systems: Spatial and multi-level models of tropical land use and cover change (LUCC) in Guatemala. Ecol. Model. 2012, 229, 64-75.

23. Alvarez, R.R., Jr. The Mexican-US border: The making of an anthropology of borderlands. Annu. Rev. Anthropol. 1995, 24, 447-470.

24. Giersch, C.P. Asian Borderlands: The Transformation of Qing China's Yunnan Frontier; Harvard University Press: Cambridge, MA, USA, 2006. 
25. Baker, J. Small Town Africa: Studies in Rural-Urban Interaction; Seminar Proceedings No. 23; Nordic Africa Institute: Uppsala, Sweden, 1990.

26. Bonnin, C.; Turner, S. At what price rice? Food security, livelihood vulnerability, and state interventions in upland northern Vietnam. Geoforum 2012, 43, 95-105.

27. Walker, R.; Homma, A.K.O. Land use and land cover dynamics in the Brazilian Amazon: An overview. Ecol. Econ. 1996, 18, 67-80.

28. Carvalho, G.O.; Nepstad, D.; McGrath, D.; de Carmen Vera Diaz, M.; Santilli, M.; Barros, A.C. Frontier expansion in the Amazon: Balancing development and sustainability. Environ. Sci. Policy Sustain. Dev. 2002, 44, 34-44.

29. Moller-Jensen, L.; Knudsen, M.H. Patterns of population change in Ghana (1984-2000): Urbanization and frontier development. GeoJournal 2008, 73, 307-320.

30. Dillman, C.D. Urban growth along Mexico's northern border and the Mexican national border program. J. Dev. Areas 1970, 4, 487-508.

31. Kusakabe, K. The politics of "opening up": Female traders on borderlands of Cambodia, Laos, Thailand and Burma (Myanmar). In On the Border of State Power: Frontier in the Greater Mekong Sub-Region; Gainsborough, M., Ed.; Routledge: Abingdon, UK, 2008; pp. 60-74.

32. Anderson, J.B.; Gerber, J. Fifty Years of Change on the US-Mexico Border: Growth, Development, and Quality of Life; University of Texas Press: Austin, TX, USA, 2009.

33. Coxhead, I.; Shively, G.; Shuai, X. Development policies, resource constraints, and agricultural expansion on the Philippine land frontier. Environ. Dev. Econ. 2002, 7, 341-363.

34. Jepson, W. Producing a modern agricultural frontier: Firms and cooperatives in eastern Mato Grosso, Brazil. Econ. Geogr. 2006, 82, 289-316.

35. Agergaard, J.; Fold, N.; Gough, K.V. Global-local interactions: Socioeconomic and spatial dynamics in Vietnam's coffee frontier. Geogr. J. 2009, 175, 133-145.

36. Eilenberg, M. Frontier constellations: Agrarian expansion and sovereignty on the Indonesian-Malaysian border. J. Peasant Stud. 2014, 41, 157-182.

37. De Koninck, R. The theory and practice of frontier development: Vietnam's contribution. Asia Pac. Viewp. 2000, 41, 7-21.

38. Lary, D. Introduction. In The Chinese State at the Borders; Lary, D., Ed.; UBC Press: Vancouver, BC, Canada, 2007; pp. 1-10.

39. Tan, S.B.-H. The struggle to control land grabbing: State formation on the Central Highlands frontier under the First Republic of Vietnam (1954-63). In On the Borders of State Power: Frontiers in the Greater Mekong Sub-Region; Gainsborough, M., Ed.; Routledge: Abingdon, UK, 2008; pp. 50-66.

40. Ellis, F. Rural Livelihoods and Diversity in Developing Countries; Oxford University Press: Oxford, UK, 2000.

41. Scoones, I. Livelihoods perspectives and rural development. J. Peasant Stud. 2009, 36, 171-196.

42. Bebbington, A. Capitals and capabilities: A framework for analysing peasant viability, rural livelihoods, and poverty. World Dev. 1999, 27, 2020-2044.

43. Long, N. Development Sociology: Actor Perspectives; Routledge: London, UK, 2001.

44. Sen, A. The Standard of Living; Cambridge University Press: Cambridge, UK, 1987. 
45. Turner, S. Making a living the Hmong way: An actor-oriented livelihoods approach to everyday politics and resistance in upland Vietnam. Ann. Assoc. Am. Geogr. 2012, 102, 403-422.

46. McCusker, B.; Carr, E. The co-production of livelihoods and land use change: Case studies from South Africa and Ghana. Geoforum 2006, 37, 790-804.

47. Rigg, J. Land, farming, livelihoods, and poverty: Rethinking the links in the rural South. World Dev. 2006, 34, 180-202.

48. General Statistics Office of Vietnam. The 2009 Vietnam Population and Housing Census: Completed Results; Central Population and Housing Census Steering Committee: Hanoi, Vietnam, 2010.

49. Dien, K. Population and Ethno-demography in Vietnam; Silkworm: Chiang Mai, Thailand, 2002.

50. MacKerras, C. Ethnic minorities in China. In Ethnicity in Asia; MacKerras, C., Ed.; RoutledgeCurzon: London, UK, 2003.

51. Michaud, J. Historical Dictionary of the Peoples of the Southeast Asian Massif; Scarecrow Press: Lanham, MD, USA, 2006.

52. Leisz, S.J.; Ha, N.T.T.; Yen, N.T.B.; Lam, N.T.; Vien, T.D. Developing a methodology for identifying, mapping and potentially monitoring the distribution of general farming system types in Vietnam's northern mountain region. Agric. Syst. 2005, 85, 340-363.

53. Corlin, C. Hmong and the land question in Vietnam: National policy and local concepts of the environment. In Hmong/Miao in Asia; Tapp, N., Michaud, J., Culas, C., Lee, G.Y., Eds.; Silkworm: Chiang Mai, Thailand, 2004; pp. 295-320.

54. World Bank. Vietnam Development Report 2008: Social Protection; World Bank: Washington, DC, USA, 2008.

55. Sikor, T. Forest policy reform in Vietnam: From state to household forestry. In Stewards of Vietnam's Upland Forests; Poffenberger, M., Ed.; Asian Forestry Network: Berkley, CA, USA; Hanoi, Vietnam, 1998; pp. 18-38.

56. McElwee, P. Reforesting "bare hills" in Vietnam: Social and environmental consequences of the 5 Million Hectare Reforestation Program. Ambio 2009, 38, 325-333.

57. McElwee, P. Becoming socialist or becoming Kinh? Government policies for ethnic minorities in the Socialist Republic of Vietnam. In Civilizing the Margins: Southeast Asian Government Policies for the Development of Minorities; Duncan, C., Ed.; Cornell University Press: Ithaca, NY, USA, 2004; pp. 182-213.

58. Hardy, A. Red Hills: Migrants and the State in the Highlands of Vietnam; Nordic Institute of Asian Studies Monographs: Copenhagen, Denmark, 2005.

59. Clement, F.; Amezaga, J.M. Linking reforestation policies with land use change in northern Vietnam: Why local factors matter. Geoforum 2008, 39, 265-277.

60. Castella, J.C.; Boissau, S.; Thanh, N.H.; Novosad, P. Impact of forestland allocation on land use in a mountainous province of Vietnam. Land Use Policy 2006, 23, 147-160.

61. Clement, F.; Orange, D.; Williams, M.; Mulley, C.; Epprecht, M. Drivers of afforestation in Northern Vietnam: Assessing local variations using geographically weighted regression. Appl. Geogr. 2009, 29, 561-576.

62. Meyfroidt, P.; Lambin, E.F. The causes of the reforestation in Vietnam. Land Use Policy 2008, $25,182-197$. 
63. Sikor, T. The allocation of forestry land in Vietnam: Did it cause the expansion of forests in the northwest? For. Policy Econ. 2001, 2, 1-11.

64. Müller, D.; Munroe, D.K. Tradeoffs between rural development policies and forest protection: Spatially explicit modeling in the Central Highlands of Vietnam. Land Econ. 2005, 81, 412-425.

65. Leisz, S.J. Dynamics of land cover and land use changes in the upper Ca river basin of Nghe An, Vietnam. Southeast Asian Stud. 2009, 47, 287-308.

66. Dao, M.T.; Kono, Y.; Yanagisawa, M.; Leisz, S.J.; Kobayashi, S. Linkage of forest policies and programs with land cover and land use changes in the Northern mountain region of Vietnam: A village-level case study. Southeast Asian Stud. 2009, 47, 244-262.

67. Pham, T.T.H.; Turner, S.; Trincsi, K. Applying a systematic review to land use land cover change in northern upland Vietnam: The missing case of the borderlands. Geogr. Res. 2015, doi:10.1111/1745-5871.12133.

68. Cuc, L.T.; Rambo, T. Bright Peaks, Dark Valleys. Bright Peaks, Dark Valleys: A Comparative Analysis of Environmental and Social Conditions and Development Trends in Five Communities in Vietnam's Northern Mountain Region; The National Political Publishing House: Hanoi, Vietnam, 2001.

69. Greene, J.C. Mixed Methods in Social Inquiry; Jossey-Bass: San Francisco, CA, USA, 2007.

70. Meyfroidt, P.; Lambin, E.F. Forest transition in Vietnam and its environmental impacts. Glob. Change Biol. 2008, 14, 1319-1336.

71. Anderson, J.R. A Land Use and Land Cover Classification System for Use with Remote Sensor Data; US Government Printing Office: Arlington, VA, USA, 1976.

72. Hurni, K.; Hett, C.; Epprecht, M.; Messerli, P.; Heinimann, A.A. Texture-based land cover classification for the delineation of a shifting cultivation landscape in the Lao PDR using landscape metrics. Remote Sens. 2013, 5, 3377-3396.

73. Cassidy, L.; Binford, M.; Southworth, J.; Barnes, G. Social and ecological factors and land-use land-cover diversity in two provinces in Southeast Asia. J. Land Use Sci. 2010, 5, 277-306.

74. Baatz, M.; Hoffman, C.; Willhauck, G. Progressing from object-based to object-oriented image analysis. In Object-Based Image Analysis: Spatial Concepts for Knowledge-Driven Remote Sensing Applications; Blaschke, T., Lang, S., Hay, G.J., Eds.; Springer: Berlin, Germany, 2008; pp. 29-42.

75. Dorren, L.K.A.; Maier, B.; Seijmonsbergen, A.C. Improved Landsat-based forest mapping in steep mountainous terrain using object-based classification. For. Ecol. Manag. 2003, 183, 31-46.

76. Vieira, M.A.; Formaggio, A.R.; Rennó, C.D.; Atzberger, C.; Aguiar, D.A.; Mello, M.P. Object based image analysis and data mining applied to a remotely sensed Landsat time-series to map sugarcane over large areas. Remote Sens. Environ. 2012, 123, 553-562.

77. Puyravaud, J.P. Standardizing the calculation of the annual rate of deforestation. For. Ecol. Manag. 2003, 177, 593-596.

78. People's Committee of Lào Cai. Quy hoạch tổng thể phát triển kinh tế - xã hội tỉnh Lào Cai đến năm 2020 [The 2020 Lào Cai economic development plan], 2008. Available online: http://laocai.gov.vn/thongtinktxh/dinhhuongphattrien/quyhoachphattrienktxh/Trang/6340461991 07564190.aspx (accessed on 27 September 2015). 
79. Socialist Republic of Vietnam. Của Chính Phủ Số 36/2000/Nd-Cp Ngày 18 Tháng 8 Năm 2000 Về Việc Điều Chỉnh Địa Giới Hành Chính Huyện Bắc Hà Để Tái Lập Huyện Si Ma Cai, Tỉnh Lào Cai [Decree No. 36/2000 / ND-CP of August 18, 2000 of the Government on the adjustment of administrative boundaries of Bắc Hà district to reestablish Si Ma Cai District, Lào Cai Province], 2000. Available online: http://thuvienphapluat.vn/archive/Nghi-dinh/Nghi-dinh-362000-ND-CP-dieu-chinh-dia-gioi-hanh-chinh-huyen-Bac-Ha-de-tai-lap-huyen-Si-Ma-Cai-tinhLao-Cai-vb46707t11.aspx (accessed on 27 September 2015).

80. Socialist Republic of Vietnam. Nghị định số 42/2009/ND-CP. Về việc phân loại đô thi [Decree 42/2009/ND-CP 7th May, 2009 on the grading of urban centers], 2009. Available online: http://www.moj.gov.vn/vbpq/en/_layouts/printeng.aspx?id=10670 (accessed on 27 September 2015).

81. Socialist Republic of Vietnam. Về Việc Điều Chỉnh Địa Giới Hành Chính Để Thành Lập Đơn Vị Hành Chính Cấp Xã, Cấp Huyện Thuộc Tỉnh Lai Châu [Adjustments of administrative boundaries to establish Administrative Units at the commune and district Levels, Lai Châu Province], 2012. Available online: http://thuvienphapluat.vn/archive/Nghi-quyet-71-NQ-CPnam-2012-dieu-chinh-dia-gioi-hanh-chinh-de-thanh-lap-don-vi-vb150870.aspx (accessed on 27 September 2015).

82. General Statistics Office of Vietnam. Socio-economical Statistical Data of 63 Provinces and Cities; Statistical Publishing House: Hanoi, Vietnam, 2009.

83. General Statistics Office of Vietnam. The 1999 Vietnam Population and Housing Census: Completed Results; Central Population and Housing Census Steering Committee: Hanoi, Vietnam, 2000.

84. Bui, T.M.H.; Schreinemachers, P.; Berger, T. Hydropower development in Vietnam: Involuntary resettlement and factors enabling rehabilitation. Land Use Policy 2013, 31, 536-544.

85. International Rivers Network. Planned Dams in Vietnam, 2001. Available online: http://www.internationalrivers.org/de/resources/planned-dams-in-vietnam-4079 (accessed on 27 September 2015).

86. Socialist Republic of Vietnam. Về Việc Thành Lập Thị Xã Lai Châu Và Thành Lập Thị Trấn Thuộc Các Huyện Tam Đường, Phong Thổ, Tỉnh Lai Châu [On the establishment of the township of Lai Châu and district headtowns of Tam Đường, Phong Thổ , Lai Châu province], 2004. Available online: http://thuvienphapluat.vn/archive/Nghi-dinh/Nghi-dinh-176-2004-NDCP-thanh-lap-thi-xa-Lai-Chau-va-thanh-lap-thi-tran-thuoc-cac-huyen-Tam-Duong-Phong-Thotinh-Lai-Chau-vb5530t11.aspx (accessed on 27 September 2015).

87. VietnamNews. PM Okays Establishment of Lai Châu City. 30 December 2013. Available online: http://vietnamnews.vn/domestic-press-highlights/249576/pm-okays-establishment-of-lai-chaucity.html (accessed on 27 September 2015).

88. Resettlement Problems Put Hydro-Plant behind Schedule. VietnamNews 21 August 2014. Available online: http://vietnamnews.vn/society/259092/resettlement-problems-put-hydro-plantbehind-schedule.html (accessed on 27 September 2015).

89. General Statistics Office of Vietnam. Results of the 2006 Rural, Agricultural and Fishery Census; Statistical Publishing House: Hanoi, Vietnam, 2007.

90. Turner, S. "Forever Hmong": Ethnic minority livelihoods and agrarian transition in upland northern Vietnam. Prof. Geogr. 2012, 64, 540-553. 
91. Novellino, D. Indigenous highlands in transition: The case of Hà Giang Province in northern Vietnam. Land Reform: Land Settl. Coop. Bull. 2000, 2, 94-107.

92. Kyeyune, V. Yielding to High Yields: Hybrid Maize and Food Security in Hà Giang Province, Northern Vietnam. Master's Thesis, McGill University, Montreal, Canada, 2014.

93. Duncan, C. Civilizing the Margins. Southeast Asian Government Policies for the Development of Minorities; Cornell University Press: Ithaca, NY, USA, 2004.

94. Socialist Republic of Vietnam. Hiến Pháp Nước Cộng Hòa Xã Hội Chủ Nghĩa Việt Nam (Sửa Đổi) [The Constitution of the Socialist Republic of Vietnam (Amended)]; Socialist Republic of Vietnam: Hanoi, Vietnam, 2013.

95. Turner, S.; Michaud, J. Imaginative and adaptive economic strategies for Hmong livelihoods in Lào Cai Province, northern Vietnam. J. Vietnam. Stud. 2008, 2, 154-186.

96. Alther, C.; Castella, J.C.; Novosad, P.; Rousseau, E.; Hieu, T.T. Impact of accessibility on the range of livelihood options available to farm households in mountainous areas of northern Viet Nam. In Doi Moi in the Mountains: Land Use Changes and Farmers' Livelihood Strategies in Bac Kan Province, Vietnam; Castella, J.C., Quang, D.D., Eds.; The Agricultural Publishing House: Hanoi, Vietnam, 2001; pp. 121-146.

97. Evans, G.; Hutton, C.; Eng, K.K. Where China Meets Southeast Asia: Social and Cultural Change in the Border Regions; St Martin's Press: New York, NY, USA, 2000.

98. Meyfroidt, P.; Vu Tan Phuong; Hoang Viet Anh. Trajectories of deforestation, coffee expansion and displacement of shifting cultivation in the Central Highlands of Vietnam. Glob. Environ. Change 2013, 23, 1187-1198.

99. Zhang, B.Q. 云南省边境 $\square$ 岸物流发展状况分析：以河口岸为例 [Analyzing logistics development at border crossing points in Yunnan: A case study on Hekou Border Crossing Point]. J. Manag. 2014, 27, 48-52.

100. Geoghegan, J.; Pritchard, L., Jr.; Ogneva-Himmelberger, Y.; Roy Chowdhury, R.; Sanderson, S.; Turner, B.L., II. "Socializing the pixel" and "pixelizing the social" in land-use and land-cover change. In People and Pixels. Linking Remote Sensing and Social Science; Liverman, D.; Moran, E.F.; Rindfuss, R.R.; Stern, P.C., Eds.; National Academy Press: Washington, DC, USA, 1998; pp. 51-69.

101. Kull, C.A. Politicizing land use change in highland Madagascar: Struggles with air photo analyses and conservation agendas. In Land Change Science, Political Ecology, and Sustainability; Brannstrom, C.; Vadjunec, J.M., Eds.; Routledge: London, UK, 2013; pp. 66-83.

102. Turner, S. Red Stamps and Gold Stars. Fieldwork Dilemmas in Upland Socialist Asia; UBC Press: Vancouver, BC, Canada, 2013.

103. Oxfam. Growing a Better Future: Expanding Rights and Choices for Small-scale Farmers in Viet Nam, Brochure; Oxfam: Hanoi, Vietnam, 2012.

104. Mackenzie, C.A.; Christensen, J.; Turner, S. Advocating beyond the academy: Dilemmas of communicating relevant research results. Qual. Res. 2015, 15,105-121.

(C) 2015 by the authors; licensee MDPI, Basel, Switzerland. This article is an open access article distributed under the terms and conditions of the Creative Commons Attribution license (http://creativecommons.org/licenses/by/4.0/). 